
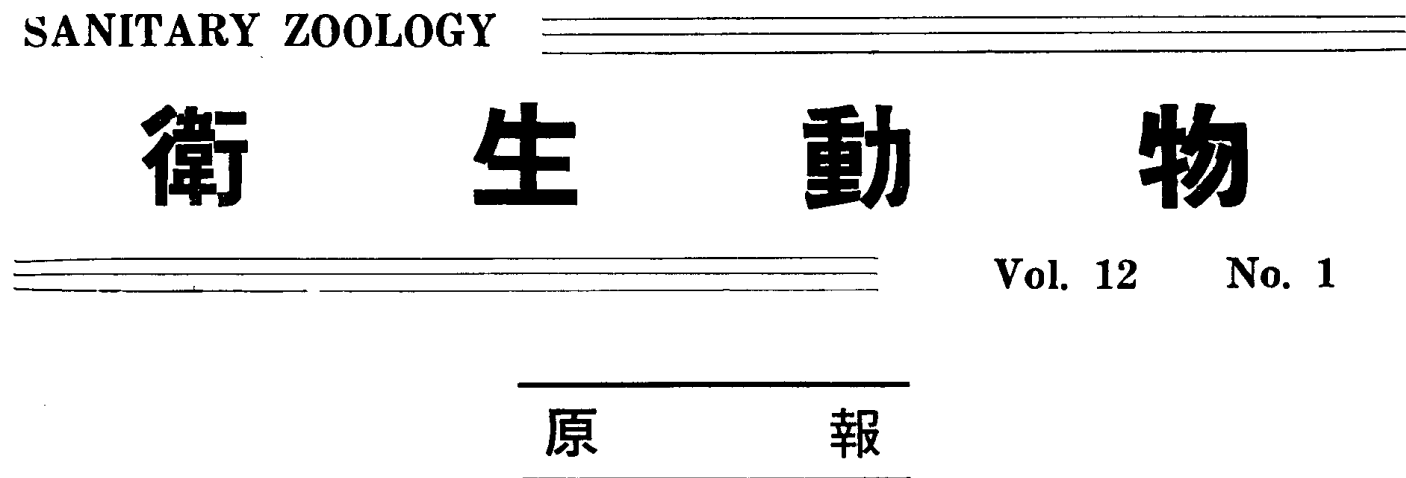

マウスに需生する Myobiidae 科のダニについて

\title{
Observation on Myobiid mites (Acarina: Myobiidae) from laboratory mice
}

\author{
松 崎 沙 和 子1)2) \\ Sawako Matsuzaki
}

\section{まえがき}

Myobiidae 科に属するダニ類は実験動物の皮膚炎と関 係があるとみなされ，諸外国においては最近その駆除の ための仕事が多くなされている．また，このダ二の宿主 は実験動物に限らず, 野外の哺乳動物や鳥類等に広くみ られるので，駆除のための仕事に入る前に種の記載は早 くから手がけられていた. まず Rodents より F. P. von Schrank(1781)が Myobia musculi を記載したのに始ま り, V. Heyden (1826), C. L. Koch (1835), A. D. Michael (1884) ら多くのダニ学者によつて初期の成果が あげられている。なかでも最も広汎な初期の研究は, S. A. Poppe (1896) によつてなされ, Myobia 属の大要 が明らかにされた．それより少しおくれては C. D. Radford (1934 6) がアメリカの Rodents, Shrews から 採集した多くの myobiid mite についての研究が注目さ れる. さらに, H. E. Ewing (1938)は myobiid mite を Cheyletidae の Myobinae 亜科として独立させ，また， 第 2 脚に 1 対の爪をもつ種類を Myobia 属から分離し

1）東京大学伝染病研究所寄生虫研究部

(指導 佐々学教授)

Department of Parasitology, the Institute for Infectious Diseases, the University of Tokyo (Chief. : Prof. Manabu Sasa)

2) 高知女子大学動物学教㗌

Zoological Laboratory, Kochi Women's University
て Radfordia 属を新設した. 最近の研究では，C. D. Radford (1948 50), E. W. Jameson (1948 9), R. F. Lawrence (1951，4) らによつて Rodents のみでなく, 他の哺乳類や鳥類から新属・新種が多数報告されてい る. Jameson(1955)はこれまでに知られた属をまとめて, これらの間の key を作成した. 以上の結果 13 属 58 種 以上が哺乳動物 (Insectivora, Chiroptera, Rodentia), 鳥類から報告されている。

本邦に扔いても実験動物を始为野外哺乳動物に多くの ダニの寄生が期待せられるばかりでなく，このダニが実 験動物渏生して宿主から吸血するところから特に実験 動物の外部寄生虫としてすでに注目さるべきものであつ た. しかし，本邦においては実験動物の飼育者によつて 着目され始めた程度で，詳細は明らかにされていない．

著者は最近皮膚炎にかかつている多数のマウスから myobiid mites を採集する機会を得たのでそれらについ て分類学的, 形態学的考察を試みた。 今回採集されたの は 2 属 2 種であるが，先述のように多くの種類が諸外国 において採集されていることから，今後の採集で更に多 くの種類が日本からも記録されることと思う．才でに著 者は野生のドブネズミから Radfordia ensifera t, ットから Myobia sp.を採集しているが，これらについ ては次の機会に報告する.

報文に入るに先立ち，本研究の機会を与えられ終始御 指導を頂いた本研究部主任佐々学教授に深甚の謝意を表 するとともに，多大の御教示を頂き，かつ標本の寄贈を 
頂いた野村達次博士，田中宽博士，福井正信博士，また 多くの御教示をいただいた高知女子大学動物学教空田中 亮教授に感謝寸る.

\section{材料および方法}

1960 年 5 月より皮膚炎にかかつているマウス 160 頭 について myobiid mites の採集定行つた. myobiid mites の寄生しているマウスの皮膚炎は頭部から肩胛部にかけ 一激しく，症状は単に粗毛のみが認められる軽度のもの から，さらにはげしいものではダニの刺口から細菌の二 次感染を受けて出血や皮膚組織の破壊が起り，脱毛部が 生し，それが進行して耳殸の消失や失明が生じるように なるものもある。このような鼠体での myobiid mites の 奇生は皮膚炎の激し、部位である頭部から肩胛部にほと んど集中しており，腹・尾部からはほとんど採集されな w.

Myobiid mites の採集方法として，マウスを吊り下げ て放置し, ダニの落下を待つ寺邑氏法は, myobiid mites ガマウスの死後も鼠体をはなれず毛を握んだままでいる 性質上好ましくなく，また，セロテープ法もやはり同様 の理由から成功率は低く使用に不向であつた，そこで最 も手閒がかかり原始的な方法ではあるが，ピンセットの 先でマウスの毛をひき抜くことが，最良の方法であるこ
とがわかつた，ダニは引き拔かれた毛の基部にしつかり からみついたままで採りだされる。これをグリノ一解剖 顕微鏡で 1 匹つうつひろいだし，ガム・クロラール液で封 大後, 検鏡した

\section{採菄結果}

著者らは上記の採集方法によつて Myobia musculi Schrank, 1781 Ł Radfordia affinis (Poppe, 1896) の 2 種を全発育期にわたつて採集することができた。発育 期は卵，前幼虫(1st larva)，後幼虫（2nd larva），前若 虫 (1st nymph), 後若虫 (2nd nymph), 成虫の各期が区 別され，C. D. Grant (1942) が M. musculi によつて 示したと拈りである。これら2種はマウスを其通の宿 主として，同一鼠体の同部位に混棲しており，初夏には M. musculi が㽵倒的に多く，まれにR. affnis が共存 するのがみられたが，秋期には数的に全く逆の関係に なり，R. affinis が優勢を示していた。

\section{記 載}

本報告では主として種間と各発育期間について，一般 形態と時に胴背ならびに脚のChaetotaxy に基うくく特 徵の比較を述心゙ることにした．胴背毛の表示記号は， Ewing (1938)の縦列方式によらないで，体の前方より後

Table 1 Measurement $(\mu)$ of dorsal setae, body length and body width in Myobia musculi.

\begin{tabular}{|c|c|c|c|c|c|c|c|c|c|c|c|c|c|c|c|c|c|c|c|}
\hline \multirow{2}{*}{ clorsal } & & \multicolumn{3}{|c|}{ Female } & \multicolumn{3}{|c|}{ Male } & \multicolumn{3}{|c|}{ 2nd nymph } & \multicolumn{3}{|c|}{ 1st numph } & \multicolumn{3}{|c|}{ 2nd larva } & \multicolumn{3}{|c|}{ 1st larva } \\
\hline & & $\# 1$ & $\# 2$ & $\# 3$ & $\# 4$ & $\# 5$ & $\# 6$ & $\# 7$ & $\# 8$ & $\# 9$ & $\# 10$ & $\# 11$ & $\# 12$ & $\# 13$ & $\# 14$ & $\# 15$ & $\# 16$ & 17 & $\# 18$ \\
\hline \multicolumn{2}{|l|}{1} & 90 & 86 & 73 & 69 & 53 & & 17 & 20 & 27 & 14 & 14 & 17 & 12 & 14 & 12 & 9 & 7 & 7 \\
\hline \multicolumn{2}{|l|}{2} & 20 & 24 & 30 & 19 & 20 & 20 & 19 & 17 & 19 & 17 & 14 & 14 & 14 & 9 & 14 & 10 & 10 & 10 \\
\hline \multirow{2}{*}{3} & a & 79 & 79 & 83 & 29 & 31 & 31 & 27 & 31 & 35 & 22 & 28 & 28 & 20 & 12 & 17 & 17 & 10 & 12 \\
\hline & $\mathrm{b}$ & 76 & 76 & 66 & 62 & 78 & 83 & 27 & 20 & 27 & 14 & 17 & 17 & 9 & 7 & 9 & 7 & 7 & 7 \\
\hline \multirow{2}{*}{4} & a & 55 & 59 & 69 & 25 & 21 & 24 & 10 & 12 & 10 & 9 & 7 & 10 & 7 & 5 & 7 & 10 & 10 & 10 \\
\hline & $\mathrm{b}$ & 79 & 69 & 82 & 98 & 79 & 95 & 59 & 52 & 57 & 48 & 41 & 24 & 10 & 17 & 14 & 10 & 10 & 10 \\
\hline \multicolumn{2}{|l|}{5} & 73 & 73 & 66 & 26 & 28 & 25 & 14 & 10 & 16 & 7 & 7 & 10 & 7 & 7 & 7 & 10 & 10 & 12 \\
\hline \multirow{2}{*}{6} & $a$ & 84 & 83 & 83 & \multirow{2}{*}{28} & \multirow{2}{*}{25} & \multirow{2}{*}{3} & & 16 & 17 & 7 & 10 & 7 & 10 & 7 & 7 & \multirow[b]{2}{*}{14} & \multirow[b]{2}{*}{14} & \\
\hline & b & 45 & 52 & 12 & & & & 17 & 16 & 14 & 10 & 14 & 10 & $10^{\prime}$ & 7 & 10 & & & 14 \\
\hline & a & 14 & 14 & 17 & \multirow[t]{2}{*}{10} & \multirow[t]{2}{*}{10} & \multirow[t]{2}{*}{7} & & 10 & 14 & 7 & 7 & 10 & 7 & 7 & 7 & \multirow{2}{*}{$\begin{array}{l}10 \\
14\end{array}$} & \multirow{2}{*}{$\begin{array}{r}7 \\
10\end{array}$} & 10 \\
\hline & $\mathrm{b}$ & 14 & 14 & 17 & & & & 14 & 10 & 10 & 9 & 7 & 10 & 5 & 7 & 7 & & & 14 \\
\hline \multirow{3}{*}{8} & a & 10 & 10 & 17 & 16 & 19 & 17 & \multirow{3}{*}{220} & \multirow{3}{*}{182} & \multirow{3}{*}{243} & \multirow{3}{*}{219} & \multirow{3}{*}{219} & & & & & & & \\
\hline & $\mathrm{b}$ & 370 & 353 & 341 & 272 & 294 & 264 & & & & & & $|192|$ & 219 & 192 & 183 & 133 & 139 & 133 \\
\hline & $\mathrm{c}$ & 7 & 10 & & 10 & 10 & 10 & & & & & & & & & & & & \\
\hline body & & 370 & 356 & 384 & 288 & 302 & 274 & 302 & 288 & 329 & 206 & 274 & 206 & 233 & 178 & 192 & 175 & 138 & 155 \\
\hline body & & 219 & 219 & 219 & 178 & 178 & 178 & 218 & 178 & 212 & 137 & 178 & 130 & 137 & 109 & 138 & 105 & 83 & 83 \\
\hline
\end{tabular}



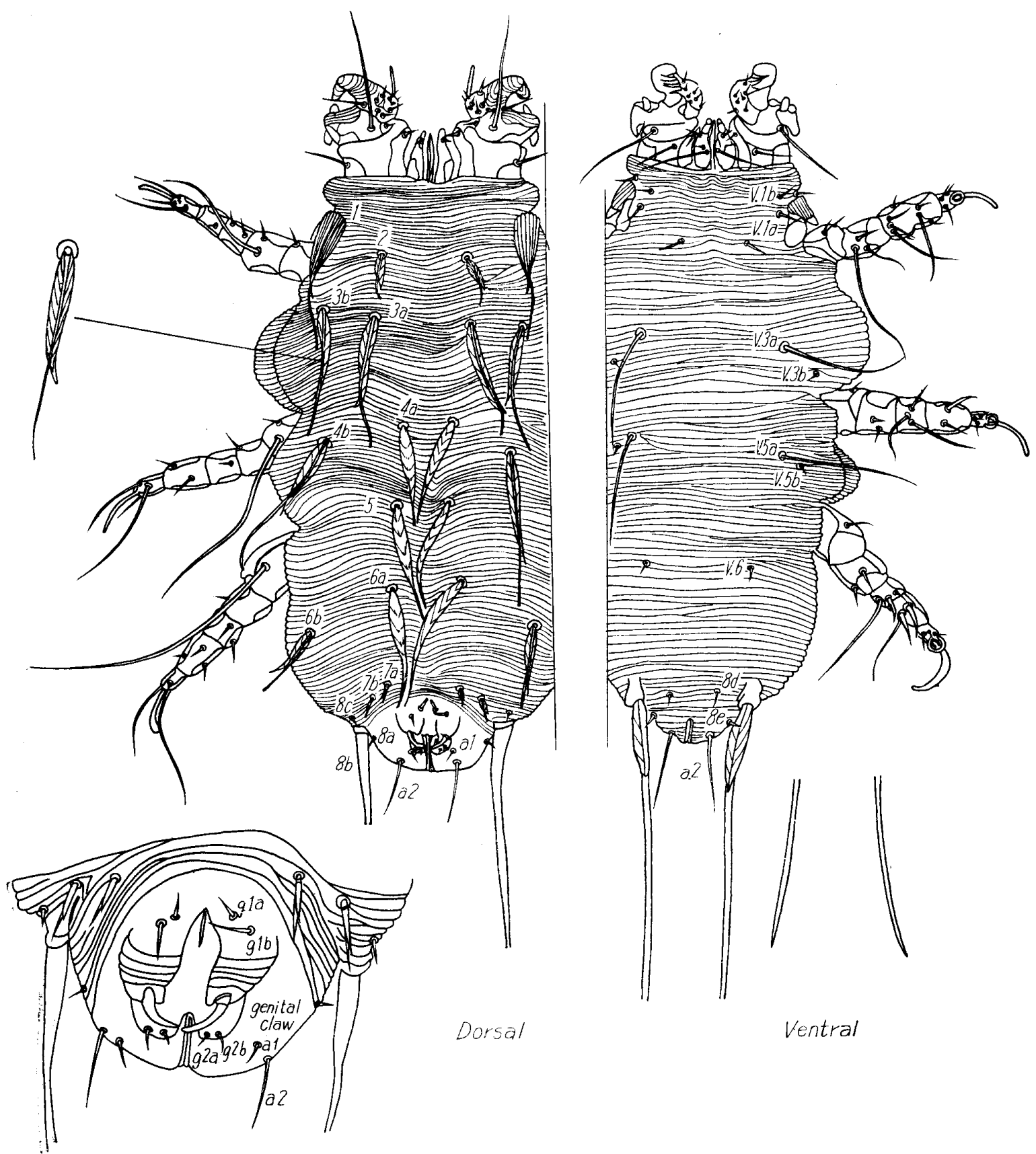

Ventral

Genital and anal area

Flg. 1 Myobia musculi, female, dorsal and ventral halves.

方に向つて横列に番号を付し, 体の後方の毛を記載しや すくした．同列の毛は正中線側よりアルファベットにて 示した. Ewing (1938) との対比は次のとおりである. 胴 背毛 1 : lateral I(Ewing によるもの), 2 : submedian I, 3a : submedian II, $3 \mathrm{~b}$ : lateral II, 4a : submedian III, $4 \mathrm{~b}$ : lateral IIT, 5 : submedian IV, $6 \mathrm{a}$ : submedian IV, 6b: lateral IV, 7a, 7b : circumanal setae, 8a, 8b, 8c, $8 \mathrm{~d}, 8 \mathrm{e}$ : 新設, $8 \mathrm{~b}$ は体後端長毛. また新たに生殖毛 (genital setae) g. と肛門毛（anal setae）a. を区別して 示した. 脚の毛は各節每に背面より番号を付して着生部 位を明らかにした，胴腹毛 v。は，胴背毛に準じた。

（1）Myobia 属と Radfordia 属との一般形態
体は長楕円形で中央部はやや幅広い，全表面に横条紋 を有し小形で，ほとんど無色の偏平なダニである．体前 端に突出する䫟体部（gnathosoma）は極めて小さく, 触 鬚（palp）は 2 節がやつと識別できる程度である. 鋏角

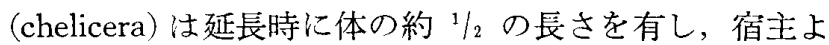
りの吸血に適する。第 1 脚は 3 節が認められるのみで, 元来汁他の脚々同様 5 節であつたものが，第 $3 ， 4 ， 5$ 節 の融合によつてそれらが 1 節となり宿主の毛を㨔む構造 に変形していることが，第 3 節に存在する毛の数から推 察される.この両属は Myobiidae 科中で, 第 1 脚の変形 の最も進んだ group である. 第 $2 \sim 4$ 脚は体中に埋没し ている基節 (coxa) と可動部である転節(trochanter) Tr., 
Table 2 Comparison of the body-chaetotaxy formula between each stages in Myobia musculi.

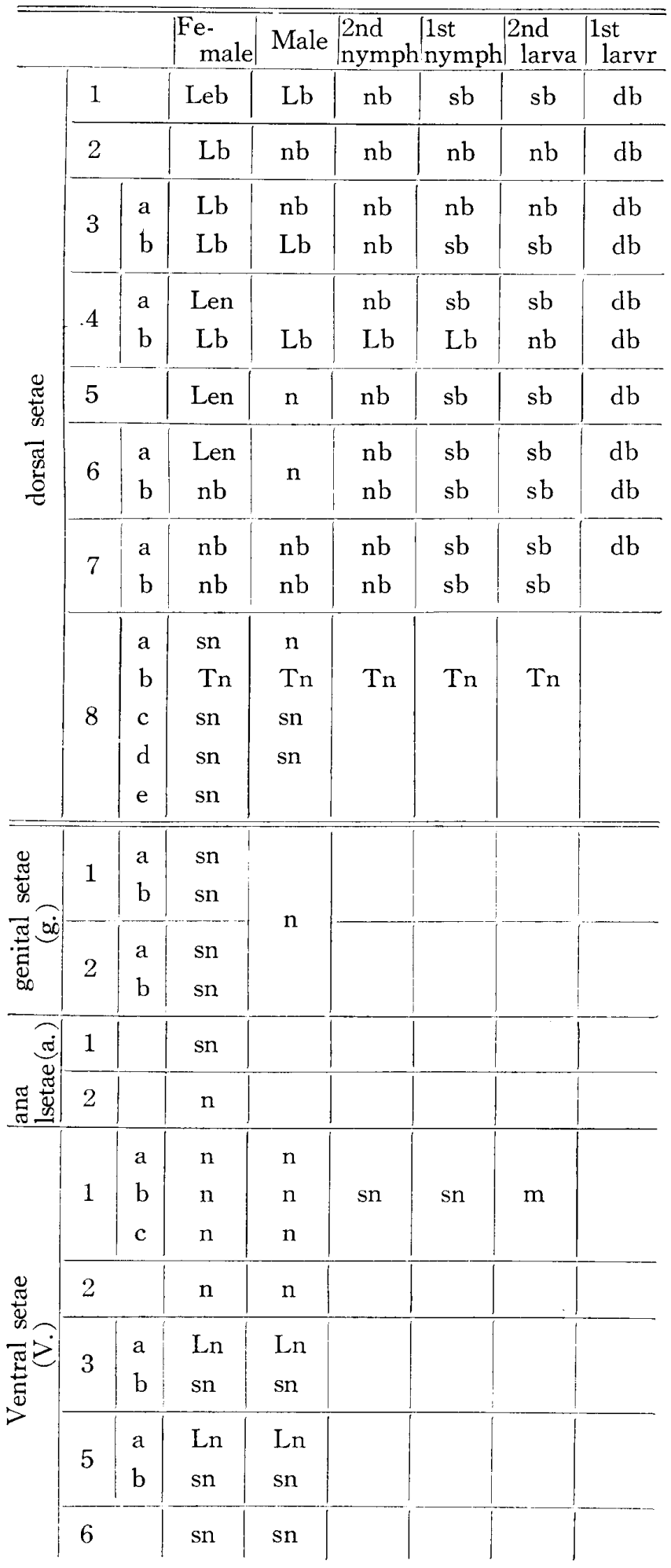

$\mathrm{m}$ : microsetae, sn: short nude setae $-8 \mu$, $\mathrm{n}$ : nude setae $8.1-30 \mu, \mathrm{Ln}$ : long nude setae $30 \mu-, \mathrm{b}$ : barbed setae, db: double barbed setae, Lb: long barbed setae, e : expanded setae, Tn: long posterior setae
腿節 (femur) Fe., 膝節 (genu) Ge., 脛節 (tibia) Ti., 跗節 (tarsus) Ta. の各 5 節よりなる. 第 2 脚の爪は $M . m u$ sculi では 1 本, R. affinis では 1 対あり, それぞれ属の 特徵をなしている，第 1 脚が毛を摑むために複雑に変形 している割に第 $2 ， 3 ， 4$ 脚は弱小である. 生殖孔は雌で は背面後端に, 雄では第 2 脚と第 3 脚間の正中線上にあ. り，排泄孔は体の後端にある.

(2) Mybia musculi の一般形態

成虫 (雌) [図 1, 表 1,2]一第 1 脚は左右相称で非常に 変形した 3 節よりなり爪をもたない.この脚の第 1 節は 幅広く，第 2 節，第 3 節に比し著しく大きい．第 3 節は 拇指状にまがり，第 2 節腹側の瘤状突起と相対してい. る. 第 $2 ， 3 ， 4$ 脚は比較的丈夫で長く，ゆるやかにまが る 1 本の爪 (enpodial claw) を跗節にもつ. 中でも第 4 脚の爪は最も長く,第 3 脚がこれに次ぎ, 第 2 脚は比較的 短い. 胴背毛は〔図 1, 表 2], 第 2 脚前方に 1 対 (1), 第 2 脚内方に 1 対 (2), 第 2 脚と第 3 脚の間に 2 対 (3a, $3 b)$ ，第 3 脚内方に 2 対 $(4 a ， 4 b)$ ，第 3 脚，第 4 脚間に 1 対 (5)，第 4 脚後方に 2 対 (6a，6b), 生殖孔域前方に 2 対 $(7 \mathrm{a}, 7 \mathrm{~b})$ よりなり，後端毛は $(8 \mathrm{a}, 8 \mathrm{~b}, 8 \mathrm{c}, 8 \mathrm{~d}, 8 \mathrm{e})$ の 5 対が存在する，後端毛 $8 \mathrm{~b}$ はほぼ体長に匹敵する長さを 有し，非常に強大である。 1，2，3a，3b，4b，6b，7a， $7 \mathrm{~b}$ は縦縞と側刺を有する。1 1 は他の胴背毛より著しく 基部が肥大し，4b は最長毛である．また胴背毛 $4 \mathrm{a} ， 5$ ， $6 \mathrm{~b}$ は他の胴背毛と異なつて側刺がなく，5は4a より長 く, 6a は 5 より長い. 2 と $6 \mathrm{~b}$ は短かく, $7 \mathrm{a}, 7 \mathrm{~b}$, 㦋 しく短い，生殖孔域には $\mathrm{g} 1, \mathrm{a}, \mathrm{b}, \mathrm{g} 2, \mathrm{a}, \mathrm{b}$ の 4 対の 短毛と内方に彎曲した 1 対の爪があり，また排泄孔域に は長, 短 2 対の肛閒毛が存在する. 胴腹毛としては第 1 脚前方に 3 対 (V1，a，b，c)，第 2 脚内方に 1 対の短毛 (V.2)があり, 第 2 脚と第 3 脚間, 第 3 脚と第 4 脚の間, に胴背毛に匹敵する長さを持つ長毛と短毛の各 1 対 (V. $3 \mathrm{a}, \mathrm{b}, \mathrm{V} .5 \mathrm{a} ， \mathrm{~b})$ があり，第 4 脚後方に 1 対の短毛(V.6) がある。

成虫 (雄) [図 2]一雌より非常に小型であり, 脚の形態 は雌上同じである。しかし胴背毛は生殖孔が体の中央に 開口寸るため雌と非常に異なる．つまり，4a，6b が存 在せず，5，6 は体の正中線上に 1 本の短毛として残る に過ぎない．生殖孔の後方にある2対の毛は側刺をも ち, 雌の生殖毛に相当するとみるよりはむしろ 7a，7bと 考えられる. 胴背毛 1 は雌のように基部が肥大せず $3 \mathrm{~b}$, $4 \mathrm{~b}$ より短かい. $4 \mathrm{~b}$ 汇雌よりやや強大である. 生殖毛は 1 対生殖口の前端にあり，肛門毛はない，陰茎 (penis) は体長の約 $1 / 2$ あり細長く鋭い.

後若虫[図 3 ]一体長は成虫よりやや小さく比較的よく 発達した 4 対の脚它もつ. しかし第 4 脚は他の脚より末 


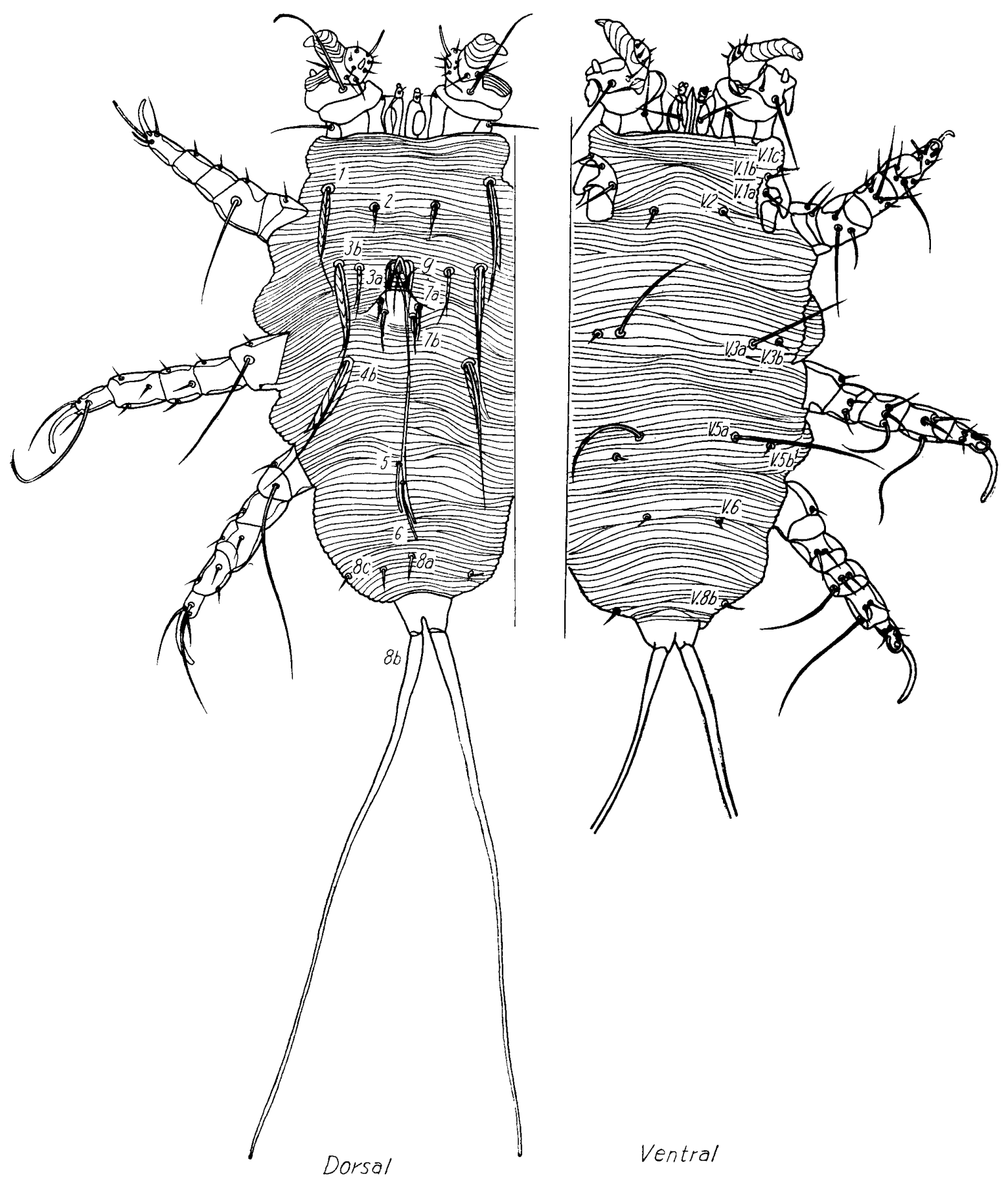

Fig. 2 M. muscuiti, male, dorsal and ventral halves. 


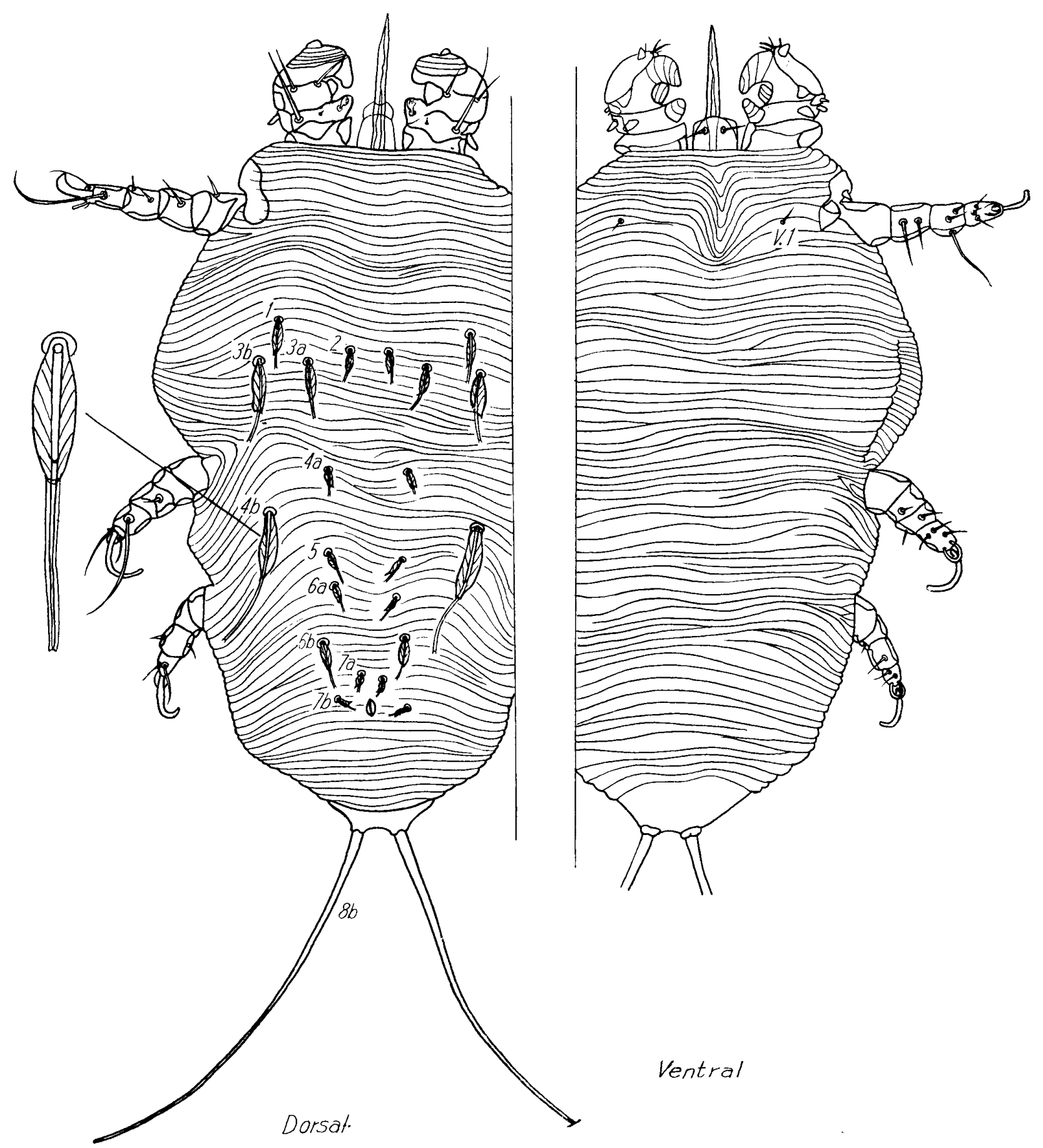

Fig. 3 M. musculi, 2nd nymph. dorsal and ventral halves. 


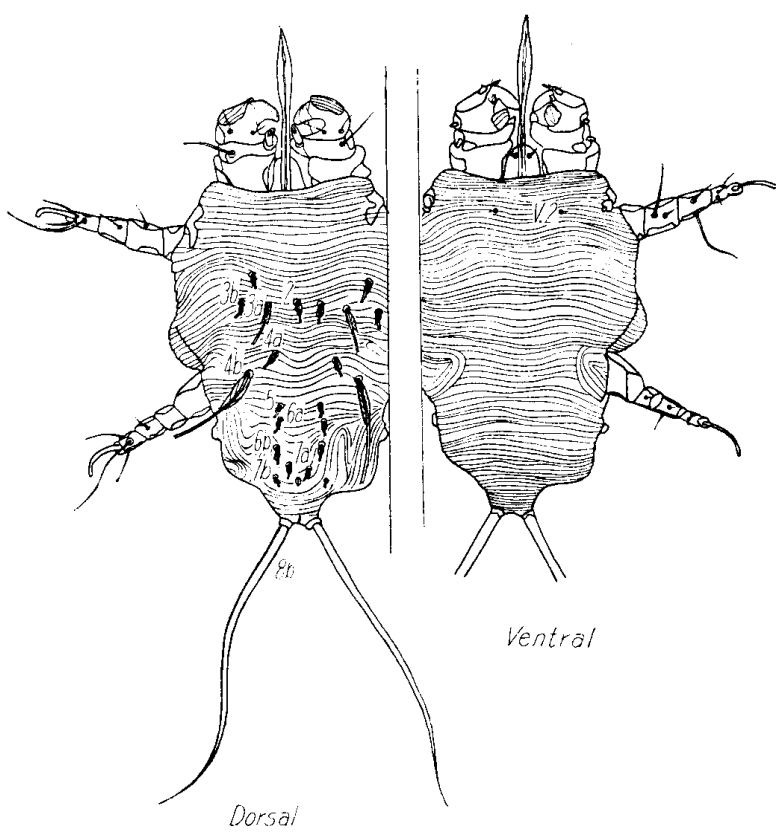

Fig. 4 M. musculi, Ist nymph, dorsal and ventral halves.

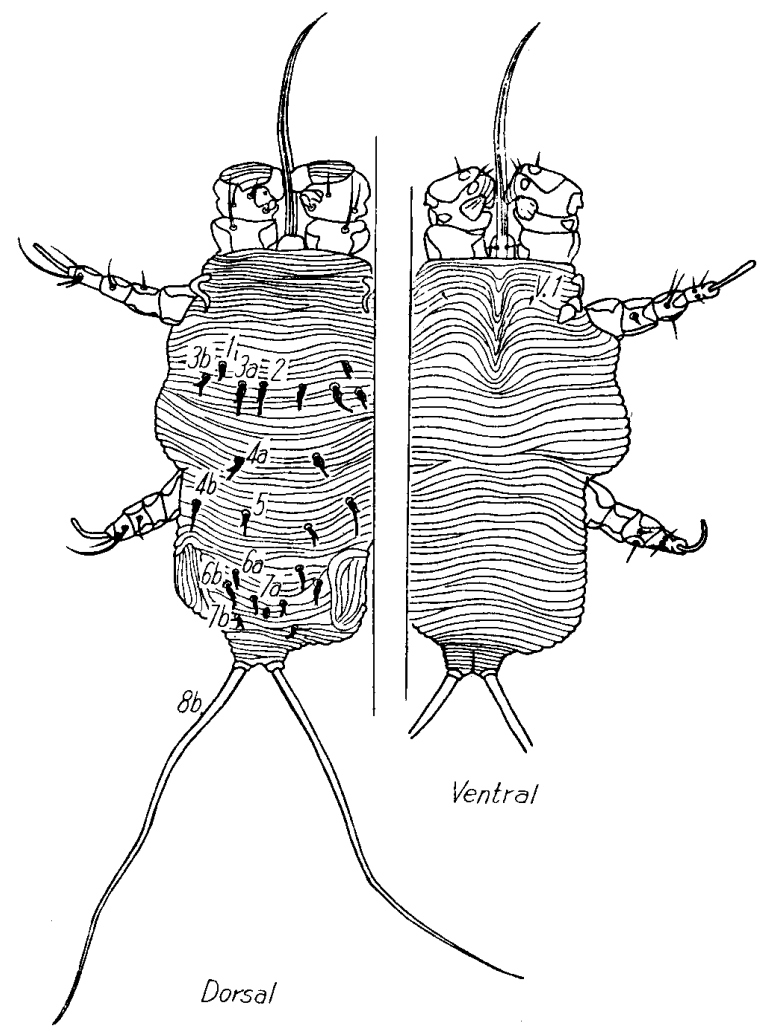

Fig. 5 M. musculi, 2nd larva, dorsal and ventral halves.

発達である. 若虫以下の若い発育期においては，第 1 脚 をのぞいて 4 節である. 第 1 脚の第 3 節は, 内方にまが り先端が瘤状に肥大した特殊な毛を有する第 2 節突起 と相対している．胴背毛は未発達ながら雌と等しい配列 にあり，この発育期の特徴は $4 b$ が成虫のそれにほぼ匹 敵する長さを持つことである。 しかし $2 ， 3 \mathrm{a} ， 3 \mathrm{~b}$ 注前・

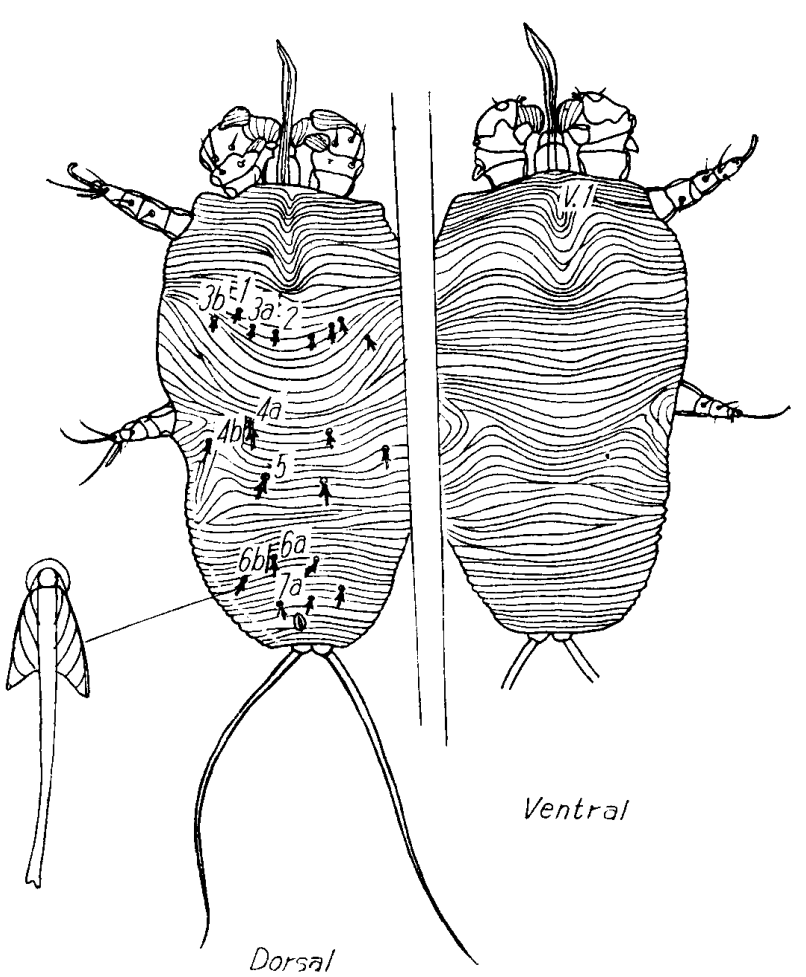

Fig. 6 M. musculi, lst larva, dorsal and ventral halves.

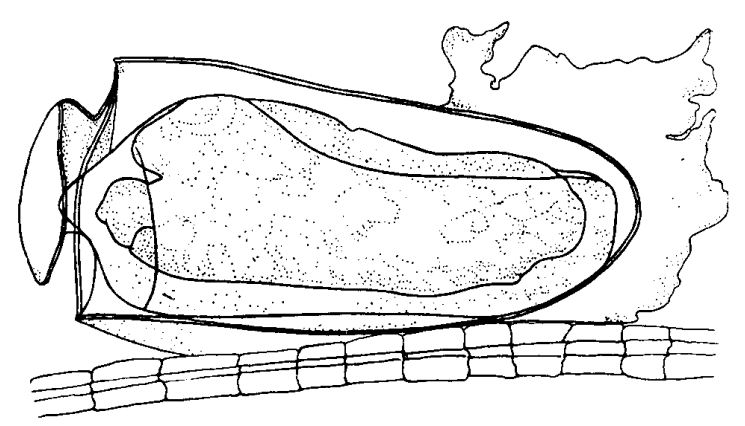

Fig. 7 M. musculi, Egg.

後の間隔が狭まり，横にほぼ一列にならび，また $6 \mathrm{~b}$ は 6a の後方に接近して縦列にならぶ点と $4 \mathrm{a}, 5,6 \mathrm{a}$ の各々 に成虫にみられなかつた側刺を有する点が䧳と異なる。

胴背毛はV.2 のみを有し他は欠けている. 生殖器はま つく存在せず．排泄孔は胴背毛 $7 \mathrm{a}$ と $7 \mathrm{~b}$ 間に位置す 万.

前若虫[4図]一第 1 3 脚は後若虫と同 じであるが 全 体に末発達である. 第 4 脚は脚芽の状態にあり.C. D. Grant (1942)の図示するごとき分節は認められない，体 は後幼虫より幅が広い. 胴背毛 $3 \mathrm{a}$ と $4 \mathrm{~b}$ がよく発達 し. 他毛より顕著に長くなる点で後幼虫と明らかに区別 される.これは脚の数とともに幼虫と若虫を区別する手 がかりとなる。

後幼虫[図 5 ]一若虫時にくらべて体はめだつて小さく 細長い. C. D. Grant (1942) が指摘しているような第 4 


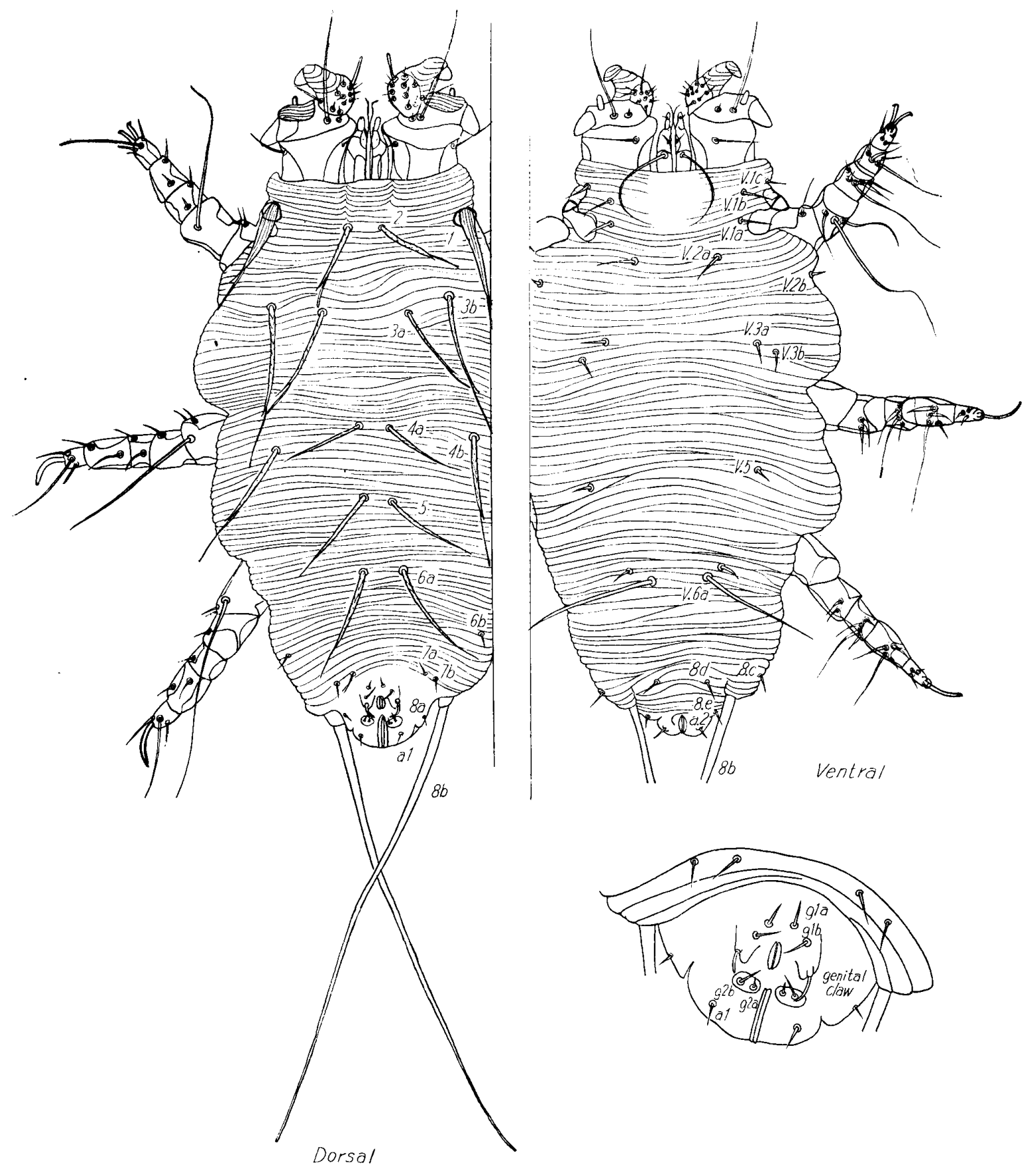

Fig. 8 Radfordia affinis, female, dorsal and ventral halves. 
Table 3 Measurements $(\mu)$ of dorsal setae, body length and body width in $R$. affinis

\begin{tabular}{|c|c|c|c|c|c|c|c|c|c|c|c|c|c|c|c|c|c|c|c|c|c|c|}
\hline \multirow{2}{*}{$\begin{array}{r}\text { dorsal } \\
\text { setae }\end{array}$} & & \multicolumn{3}{|c|}{ Female } & \multicolumn{3}{|c|}{ Male } & \multicolumn{3}{|c|}{$\begin{array}{l}\text { 2nd nymph } \\
\text { (female type) }\end{array}$} & \multicolumn{3}{|c|}{$\begin{array}{l}\text { 2nd nymph } \\
\text { (male type) }\end{array}$} & \multicolumn{3}{|c|}{ 1st nymph } & \multicolumn{3}{|c|}{ 2nd larva } & \multicolumn{3}{|c|}{ 1st larva } \\
\hline & & $\# 1$; & $\# 2$ & $\# 3$ & $\# 4$ & $\# 5$ & $\# 6$ & $\# 7:$ & $\# 8$ & $\# 9 \neq$ & $\# 10$ \# & $\# 11 \mid$ & $|\# 12|$ & $\# 13$ & $|\# 14| \neq$ & $|\# 15|$ & $\# 16 \mid \neq$ & $\# 17 \neq$ & $\# 18 \neq$ & $\mid \# 19$ & $\# 20$ \# & $\# 21$ \\
\hline 1 & & 72 & 69 & 62 & 60 & 57 & 55 & 39 & 57 & 40 & 6 & 26 & 18 & 11 & 11 & 6 & 5 & 6 & 4 & 2 & 1 & 3 \\
\hline 2 & & 69 & 46 & 39 & 12 & 12 & 12 & 15 & 15 & 18 & 5 & 7 & 9 & 5 & 6 & 7 & 5 & 4 & 4 & 5 & 4 & 4 \\
\hline 3 & $\begin{array}{l}a \\
b\end{array}$ & $\begin{array}{l}77 \\
92\end{array}$ & $\begin{array}{r}66 \\
100\end{array}$ & $\begin{array}{l}85 \\
89\end{array}$ & $\begin{array}{l}17 \\
77\end{array}$ & $\begin{array}{l}15 \\
92\end{array}$ & $\begin{array}{l}20 \\
89\end{array}$ & $\begin{array}{l}34 \\
83\end{array}$ & $\begin{array}{l}31 \\
85\end{array}$ & $\begin{array}{r}28 \\
102\end{array}$ & $\begin{array}{l}11 \\
71\end{array}$ & $\begin{array}{l}16 \\
70\end{array}$ & $\left|\begin{array}{l}14 \\
86\end{array}\right|$ & $\begin{array}{r}9 \\
66\end{array}$ & $\begin{array}{l}10 \\
59\end{array}$ & $\begin{array}{r}9 \\
60\end{array}$ & $\begin{array}{r}5 \\
18\end{array}$ & $\begin{array}{r}4 \\
41\end{array}$ & $\begin{array}{r}7 \\
11\end{array}$ & $\begin{array}{l}3 \\
3\end{array}$ & $\begin{array}{l}4 \\
2\end{array}$ & $\begin{array}{l}3 \\
3\end{array}$ \\
\hline 4 & $\begin{array}{l}\mathrm{a} \\
\mathrm{b}\end{array}$ & $\begin{array}{l}54 \\
68\end{array}$ & $\begin{array}{l}54 \\
74\end{array}$ & $\begin{array}{l}54 \\
59\end{array}$ & 77 & 85 & 82 & $\begin{array}{r}46 \\
8\end{array}$ & $\begin{array}{r}46 \\
8\end{array}$ & $\begin{array}{r}44 \\
7\end{array}$ & $\begin{array}{l}8 \\
3\end{array}$ & $\begin{array}{r}18 \\
9\end{array}$ & $\begin{array}{l}18 \\
11 \\
\end{array}$ & 11 & 14 & 7 & 6 & 7 & 8 & $\begin{array}{r}11 \\
8\end{array}$ & $\begin{array}{l}13 \\
10\end{array}$ & $\begin{array}{r}11 \\
9\end{array}$ \\
\hline 5 & & 59 & 60 & 62 & 18 & 15 & 15 & 18 & $15 \mid$ & 18 & 5 & 5 & 5 & 2 & 1 & 1 & 1 & 1 & 1 & 11 & 14 & 11 \\
\hline 6 & $\begin{array}{l}\mathrm{a} \\
\mathrm{b}\end{array}$ & $\begin{array}{r}62 \\
8\end{array}$ & $\begin{array}{r}65 \\
8\end{array}$ & $\begin{array}{r}68 \\
9\end{array}$ & 18 & 18 & 15 & $\begin{array}{l}31 \\
17\end{array}$ & \begin{tabular}{|l|}
29 \\
18
\end{tabular} & $\begin{array}{l}32 \\
35\end{array}$ & $\begin{array}{l}15 \\
25\end{array}$ & $\begin{array}{l}18 \\
26\end{array}$ & $\begin{array}{l}18 \\
25\end{array}$ & $\begin{array}{r}9 \\
12\end{array}$ & $\begin{array}{l}10 \\
10\end{array}$ & $\begin{array}{l}11 \\
11\end{array}$ & $\begin{array}{l}7 \\
7\end{array}$ & $\begin{array}{l}11 \\
13\end{array}$ & $\begin{array}{l}11 \\
10\end{array}$ & $\begin{array}{l}14 \\
14\end{array}$ & $\begin{array}{l}14 \\
14\end{array}$ & $\begin{array}{l}15 \\
14\end{array}$ \\
\hline 7 & $\begin{array}{l}\mathrm{a} \\
\mathrm{b}\end{array}$ & $\begin{array}{r}11 \\
9\end{array}$ & $\begin{array}{l}9 \\
9\end{array}$ & $\begin{array}{l}8 \\
8\end{array}$ & 9 & 11 & 11 & $\begin{array}{r}20 \\
5\end{array}$ & $\left|\begin{array}{r}22 \\
5\end{array}\right|$ & $\begin{array}{r}35 \\
5\end{array}$ & $\begin{array}{r}23 \\
3\end{array}$ & $\begin{array}{r}25 \\
4\end{array}$ & $\mid \begin{array}{r}25 \\
7\end{array}$ & $\mid \begin{array}{r}17 \\
3\end{array}$ & $\left|\begin{array}{r}11 \\
3\end{array}\right|$ & $\begin{array}{r}13 \\
3\end{array}$ & $\begin{array}{l}8 \\
3\end{array}$ & $\begin{array}{r}13 \\
4\end{array}$ & $\begin{array}{r}11 \\
3\end{array}$ & 11 & 13 & 11 \\
\hline 8 & $\begin{array}{l}\mathrm{a} \\
\mathrm{b}\end{array}$ & $\begin{array}{r}9 \\
279\end{array}$ & $\begin{array}{r}9 \\
286\end{array}$ & 293 & $\mid \begin{array}{r}5 \\
286\end{array}$ & $\begin{array}{r}5 \\
286\end{array}$ & $\begin{array}{r}5 \\
276\end{array}$ & $\begin{array}{r}3 \\
221\end{array}$ & $\begin{array}{r}5 \\
228\end{array}$ & $\begin{array}{r}4 \\
242\end{array}$ & $\begin{array}{r}2 \\
207\end{array}$ & $\begin{array}{r}5 \\
235\end{array}$ & $\begin{array}{r}7 \\
224\end{array}$ & 190 & 186 & 179 & 173 & 179 & $\mid 175$ & 97 & 123 & 112 \\
\hline BL & & 497 & 438 & 348 & 311 & 293 & 297 & $262 \mid$ & 248 & 336 & 276 & 242 & 247 & 252 & 242 & 233 & $207 \mid$ & $|209|$ & 193 & 183 & 182 & 224 \\
\hline BW & & & 207 & 176 & $|171|$ & 152 & 152 & 190 & 173 & 210 & 183 & 172 & 175 & 173 & 168 & 165 & 138 & $|147|$ & 133 & 121 & 119 & 165 \\
\hline
\end{tabular}

Table 4 Frequency in number of dorsal setae $(4,5,6)$ for males of $R$. affinis.

\begin{tabular}{l|r|r|r} 
number of setae & 1 & 2 & 3 \\
number of specimens & 2 & 13 & 3
\end{tabular}

脚原基はみあたらず， 3 対の脚があるのみである．第 2 , 第 3 脚は丈夫な大きい爪有する. 胴背毛は前若虫 の毛と性質も数も似ているが，す心゙て極めて小さく $3 \mathrm{~b}$, 4b が他毛より大きさに扔いて発達していない.

前幼虫[図 6 ]一体長は雌のほぼ $1 / 2$ に過ぎず，3対の 脚も著しく貧弱であるが，第 1 脚以外は 4 節よりなる. 第 3 脚の躈節には後若虫期以後の爪に相当寸る長毛があ るのみで爪はない，背毛は前方 $1,2,3 \mathrm{a} ， 3 \mathrm{~b}$ が非常に短 い短毛で,それより後方の毛は比較的よく発達している. この発育期の胴背毛は他の発育期と異なり, 両側に 1 本 の側刺があり，その両側刺間に薄い膜がはられている.

卵[図 7]一宿主の毛の根元に 1 個ぶつ産みつけられ 一見シラミ卵に類似寸る. 卵形は長径約 $150 \mu$, 短径約 $60 \mu$ の長棈円形でその一端が開いて幼虫が卯化する.

(3) Radfordia affinis の一般形態

成虫 (此) [図 8, 表 3，5]一第 1 脚は左右相称で， 3 節 よりなり，爪を持たない：この脚の第 1 節は長さが幅の
約 2 倍あり， $2 ， 3$ 節より顕著に長い。すなわち $M$. musculi とこの第 1 節の形で容易に区別できる. 第 2 節 には腹面と外側面に突起があり，第 3 節の拇指状構造と 相対している. 第 2 脚は跗節に強く彎曲した, 短いほぼ 相称の 1 対の爪を有する．第 $3 ， 4$ 脚は各 1 本の細長い， ゆるやかに彎曲した，鋭い爪を持つ. 第 $2 ， 3 ， 4$ 脚は各 5 節である. 胴背毛は総体に M. musculi より細長い が，その配列は同種と同じであり，相異点は毛の性質と 長さにある。すなわち胴背毛 2 は長く，6b はまつたく 短い. Ewing によると $6 \mathrm{~b}$ は久ケていると記載されて いるが，側刺のない短毛が存在する。 また $7 \mathrm{a} ， 7 \mathrm{~b}$ は側 刺を持たない. 肛門毛は a. 2 が M. musculi のように 長くない，生殖毛 $\mathrm{g} 1 ， \mathrm{a}, \mathrm{b}, \mathrm{g} 2, \mathrm{a}, \mathrm{b}$ 㵋弱である. 胴腹毛は V. 3 a, V.5 が短毛で, V.5b はなく, V.6 a, $\mathrm{b}$ が長・短の 1 対になる点 M. musculi と異なる.

成虫 (雄) [図 9]一雌上り体注非常に小さい. 脚と爪の 形は雌上変らず，胴背毛は 1 が雌のように特に強大でな い. 生殖孔が胴背面中央に位置することから， $4 \mathrm{a}, 6 \mathrm{~b}$ は 消失し， $5 ， 6$ は生殖孔後方正中線上に短毛として残る. ここに注意すべきは，生殖孔後方正中線上にある毛の出 現数に，個体間の変異があることである. S. A. Popps, (1896), C. D. Radford (1935)の記載は 3 本 (4a，5，6 
Table 5 Comparison of the body-chaetotaxy formula between each stages in $R$. affinis.

\begin{tabular}{|c|c|c|c|c|c|c|c|c|c|}
\hline & & & Female & Male & $\begin{array}{l}\text { 2nd nymph } \\
\text { (female } \\
\text { type) }\end{array}$ & $\begin{array}{c}\text { 2nd nymph } \\
\text { (male } \\
\text { type) }\end{array}$ & 1st nymph & 2nd larva & 1st larva \\
\hline & 1 & & Leb & $\mathrm{Lb}$ & $\mathrm{Lb}$ & $\mathrm{sb}$ & $\mathrm{sb}$ & $\mathrm{sb}$ & $\mathrm{m}$ \\
\hline & 2 & & $\mathrm{Lb}$ & $\mathrm{nb}$ & $\mathrm{nb}$ & $\mathrm{sb}$ & $\mathrm{sb}$ & $\mathrm{sb}$ & $\mathrm{m}$ \\
\hline & 3 & a & $\mathrm{Lb}$ & $\mathrm{nb}$ & $\mathrm{Lb}$ & $\mathrm{sb}$ & $\mathrm{sb}$ & $\mathrm{sb}$ & $\mathrm{m}$ \\
\hline & 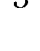 & $\mathrm{b}$ & Lb & $\mathrm{Lb}$ & $\mathrm{Lb}$ & $\mathrm{Lb}$ & $\mathrm{Lb}$ & $\mathrm{nb}$ & $\mathrm{m}$ \\
\hline & 4 & a & $\mathrm{Ln}$ & & $\mathrm{Lb}$ & $\mathrm{sb}$ & $\mathrm{sb}$ & $\mathrm{sb}$ & $\mathrm{db}$ \\
\hline & & b & $\mathrm{Lb}$ & $\mathrm{Lb}$ & $\mathrm{sb}$ & $\mathrm{sb}$ & & & $\mathrm{db}$ \\
\hline ت્ & 5 & & Ln & $\mathrm{n}$ & $\mathrm{nb}$ & $\mathrm{sb}$ & $\mathrm{m}$ & $\mathrm{m}$ & $\mathrm{db}$ \\
\hline $\bar{Z}$ & 6 & a & Ln & & $\mathrm{Lb}$ & $\mathrm{sb}$ & $\mathrm{sb}$ & $\mathrm{sb}$ & $\mathrm{db}$ \\
\hline 8 & & $\mathrm{~b}$ & $\mathrm{n}$ & 11 & $\mathrm{nb}$ & $\mathrm{nb}$ & sb & $\mathrm{sb}$ & $\mathrm{db}$ \\
\hline & 7 & a & $\mathrm{n}$ & & $\mathrm{nb}$ & $\mathrm{nb}$ & $\mathrm{nb}$ & $\mathrm{sb}$ & $\mathrm{db}$ \\
\hline & & b & $\mathrm{n}$ & & $\mathrm{sb}$ & $\mathrm{sb}$ & $\mathrm{sb}$ & $\mathrm{m}$ & \\
\hline & & a & sn & sn & $\mathrm{m}$ & $\mathrm{m}$ & $\mathrm{m}$ & & \\
\hline & & $\mathrm{b}$ & $\operatorname{Tn}$ & $\mathrm{Tn}$ & Tn & $\operatorname{Tn}$ & $\operatorname{Tn}$ & $\operatorname{Tn}$ & Tn \\
\hline & 8 & $c$ & sn & sn & & & & & \\
\hline & & d & $\mathrm{n}$ & & & & & & \\
\hline & & $\mathrm{e}$ & sn & & & & & & \\
\hline $\mathscr{\Xi}$ & 1 & $\mathrm{a}$ & sn & sn & & & & & \\
\hline & 1 & b & sn & claw-like & & & & & \\
\hline$\stackrel{\widetilde{G}}{ت}$ & (1) & $\mathrm{a}$ & sn & sn & & & & ! & \\
\hline$\infty$ & 2 & b & sn & sn & & & & & \\
\hline$\stackrel{\mathscr{J}}{\mathbb{W}}$ & 1 & & sn & & & & & & \\
\hline$\underset{\Xi}{\tilde{\sigma}} \cong$ & 2 & & sn & & & & & & \\
\hline & & a & $\mathrm{n}$ & $\mathrm{n}$ & & & & & \\
\hline & 1 & $\mathrm{~b}$ & $\mathrm{n}$ & $\mathrm{n}$ & sn & sn & sn & sn & sn \\
\hline & & c & $\operatorname{sn}$ & sn & & & & & \\
\hline & 2 & $\mathrm{a}$ & $\mathrm{n}$ & $\mathrm{n}$ & & & & & \\
\hline 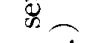 & & b & $\mathrm{sn}$ & & & & & & \\
\hline & 3 & a & $\mathrm{n}$ & sn & $\mathrm{sn}$ & sn & $\mathrm{Cn}$ & on & \\
\hline$=$ & & b & $\mathrm{n}$ & $\mathrm{sn}$ & sn & sn & & S1 & 311 \\
\hline & 5 & & $\mathrm{n}$ & sn & sn & sn & sn & sn & \\
\hline & 6 & $\begin{array}{l}\mathrm{a} \\
\mathrm{b}\end{array}$ & $\begin{array}{l}\mathrm{Ln} \\
\mathrm{n}\end{array}$ & $\begin{array}{l}\text { Ln } \\
\text { sn }\end{array}$ & $\begin{array}{l}\mathrm{sn} \\
\mathrm{sn}\end{array}$ & $\begin{array}{l}\mathrm{sn} \\
\mathrm{sn}\end{array}$ & $\mathrm{m}$ & & \\
\hline
\end{tabular}

$\mathrm{m}$ : microsetae, sn: short nude setae $-8 \mu, \mathrm{n}:$ nude setae $8.1-30 \mu, \mathrm{Ln}$ : long nude setae $30 \mu-, \mathrm{b}$ : barb setae, $\mathrm{db}$ : double barbs setae, Lb: long barb setae, e : expanded setae, $\mathrm{Tn}$ : long posterior setae 


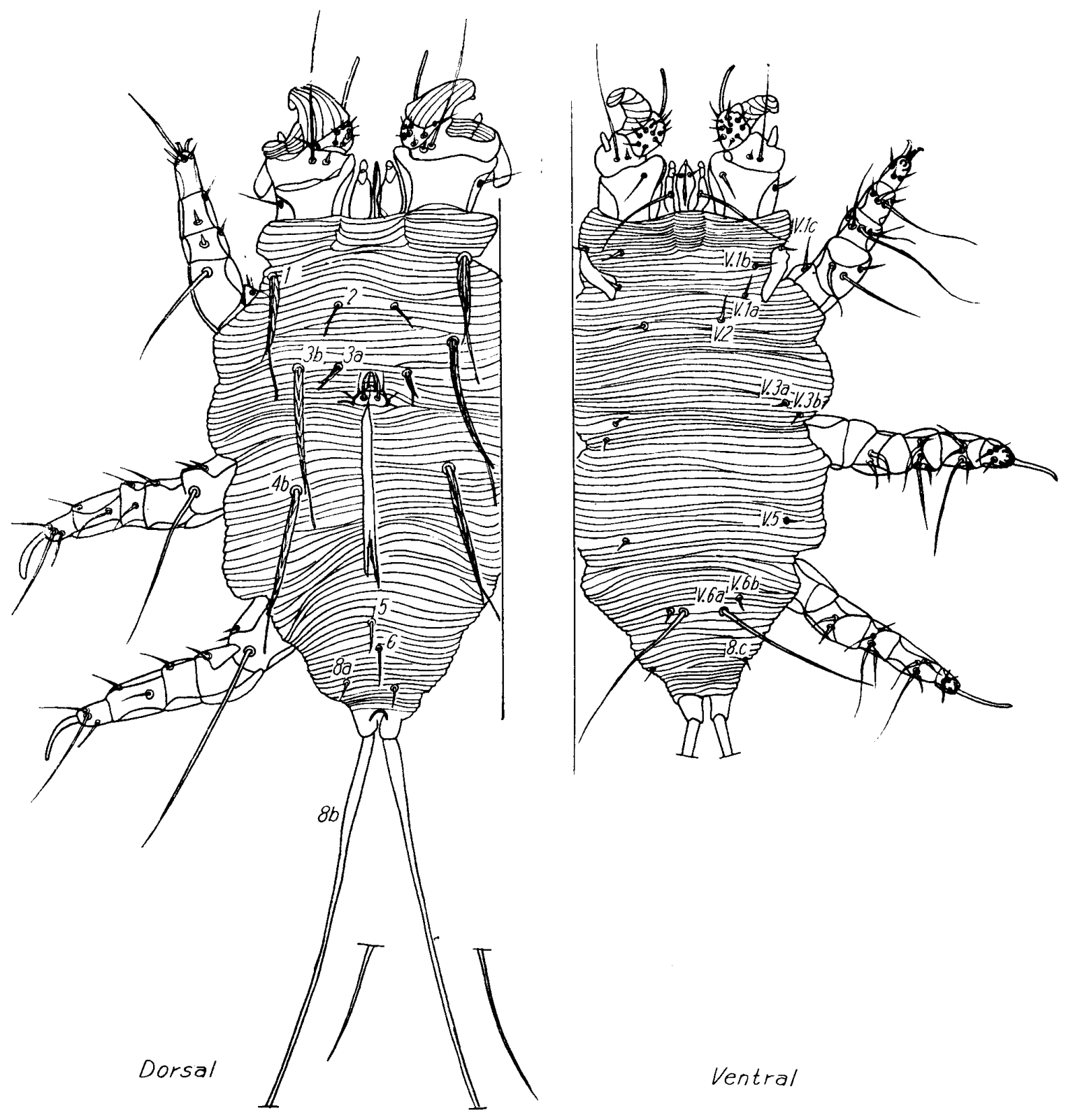

Fig. 9 Radfordia affinis, Male, dorsal and ventral halves. 


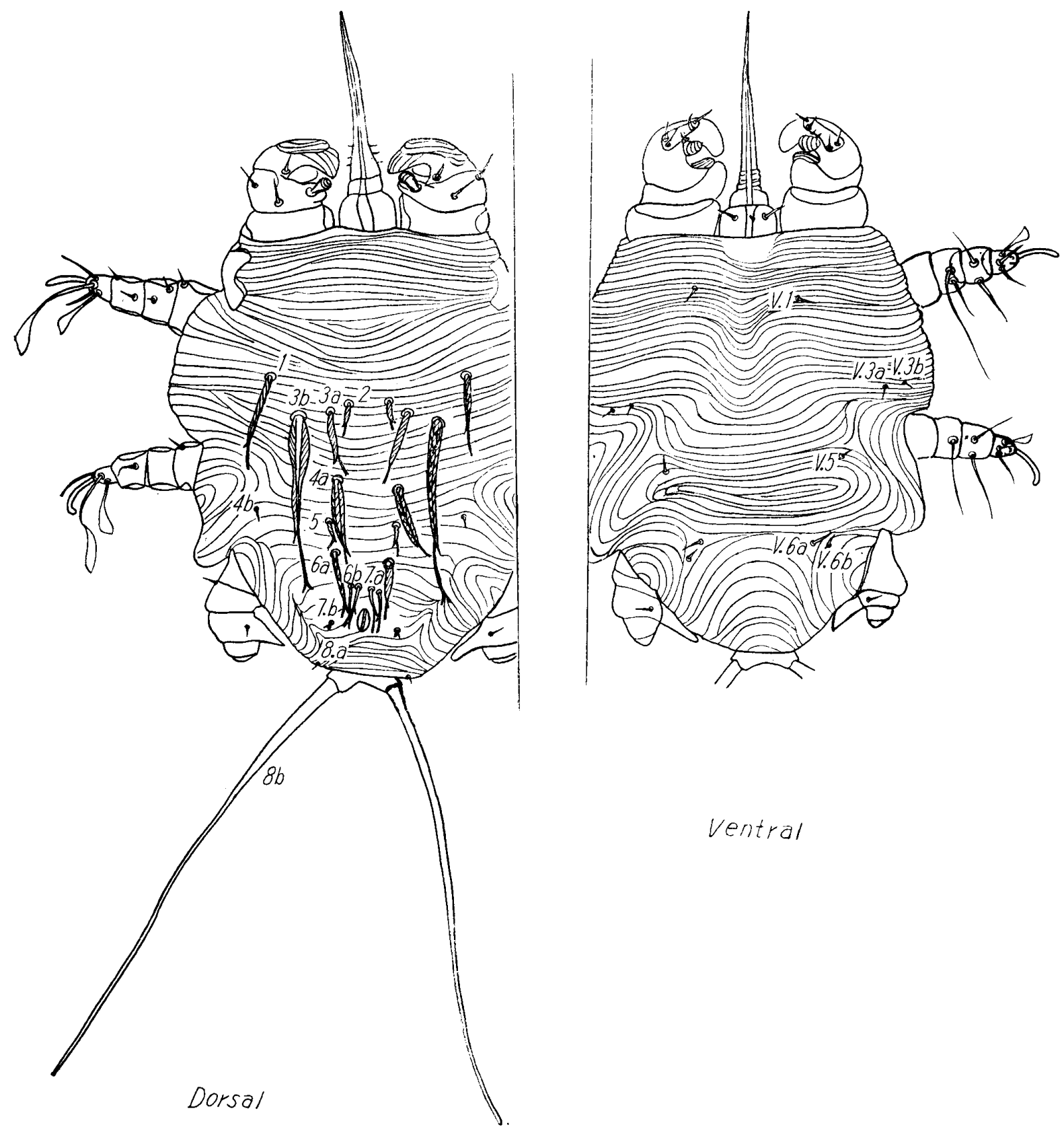

Fig. 10 Radfordia affinis, 2nd nymph (female type) 

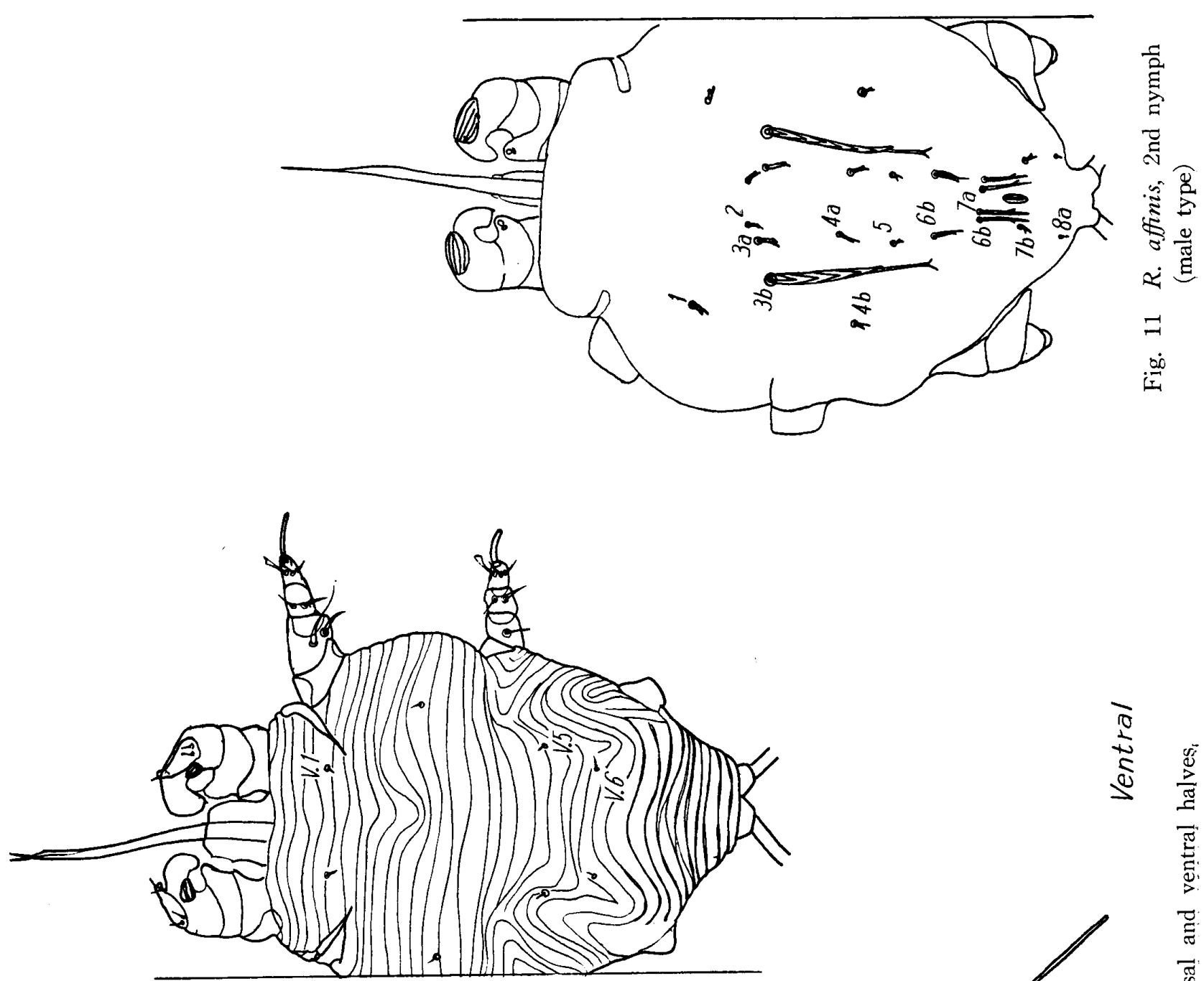

$\frac{\sqrt{2}}{\sqrt{2}}$

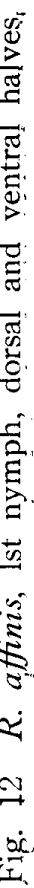


に相当）であり，C. D. Radford（1949）の図によると1 本であるが，今回の採集では，この外 2 本のものも多数 見出された．18個体について調べた結果，第 4 表に示 すごとくである.

これらの変更は，この毛が 雌の胴背毛 $4 a ， 5 ， 6$ に相 当するのでその内いずれかが出現したり欠放たりするも の上考えれば不自然でない. 生殖毛は g.1b が爪状であ るが，他汇雌と等しい．肚門毛は存在しない，胴腹毛は 雌上闹じである. 陰茥は体長の $1 / 3$ で M. musculiよ り短く，棒状で先端が急に細る。

後若虫[図 10,11 ]一体長は雌の $2 / 3$ 位に過ぎず，幅広 いことで M. musculi の後若虫と一見区分される．体 長に比し顎体部は大きく, 鋏角もまた長大である。第 1 脚は 3 節よりなり，第 3 節は内側に彎曲して第 2 節の突 起と相対している. 第 2,3 脚は 4 節で， 1 本の長い爪 を持つ. 第 4 脚は 4 節が識別せられるが，第 2 節内側に 突起を持つ特異な形態を有し, 附属毛は微毛 2 本を数え るのみである。この突起は第 1 脚, 第 2 節の突起と相同 と考えられる．胴背毛は第 2 脚と第 3 脚の間から第 1 列 が始まり，各毛間の前後の間隔は狭まつている.この 発育期の特徴は $3 \mathrm{~b}$ の発達によつて示され, この毛の基 部は成虫よりも肥大しており, 先が明らかに二叉をな す. 特にこの $3 \mathrm{~b}$ の発達することは，若虫期を通じて M. musculi の $4 \mathrm{~b}$ と比較対照され, 種の特徴として重 要である. 肛門毛は存在しない、生殖器はなく, 生殖毛 もない，胴腹毛はV.6a が短毛で，V.1b，c と V.2 が ない.

前若虫[図 12]一第 2 3 脚は 4 節で短い。第 4 脚は原 基のみが存在する. 胴背毛は $3 \mathrm{~b}$ が著しく発達している 点と $8 \mathrm{a}$ の出現以外は後幼虫と異ならず発達は覀い. 胴 腹毛は後若虫の V.4a，V.6b が存在しない.

後幼虫[図 13]一体は若虫にくらべて著しく小さく成 虫の $1 / 2$ 以下である. 胴背毛湔若虫とほとんど変らな いが，3b が前若虫ほど長くない，この発育期から成虫 の $7 \mathrm{~b}$ に相当する毛が肛門の両側に生ずる.V.1，V.3， $\mathrm{V} .5$ の胴腹毛を持つ.

前幼虫[図 14]一体長が雌の $1 / 3$ 位で, 体後端毛 $8 \mathrm{~b}$ は 体長の $1 / 2$ 以下で鋏角が顥著である. 胴背毛は $1 \sim 3$ 列が 末発達でやつと識別される位である。しかし 6b,7a， は 若虫時代の長さを持つ。この発育期の特徴として $M$. musculi と同じく胴背毛は雨側に側刺を有する. $M$. musculi では第 3 脚に爪を持たず長毛がこれに置き変つ ているが，この種では小さい爪がある。

卵一M. musculi と類似の形を持ち識別し難い.

(4) M. musculi と R. affinis の leg-chaetotaxy 両種は毛の構成が類似しているので，各節を構成する

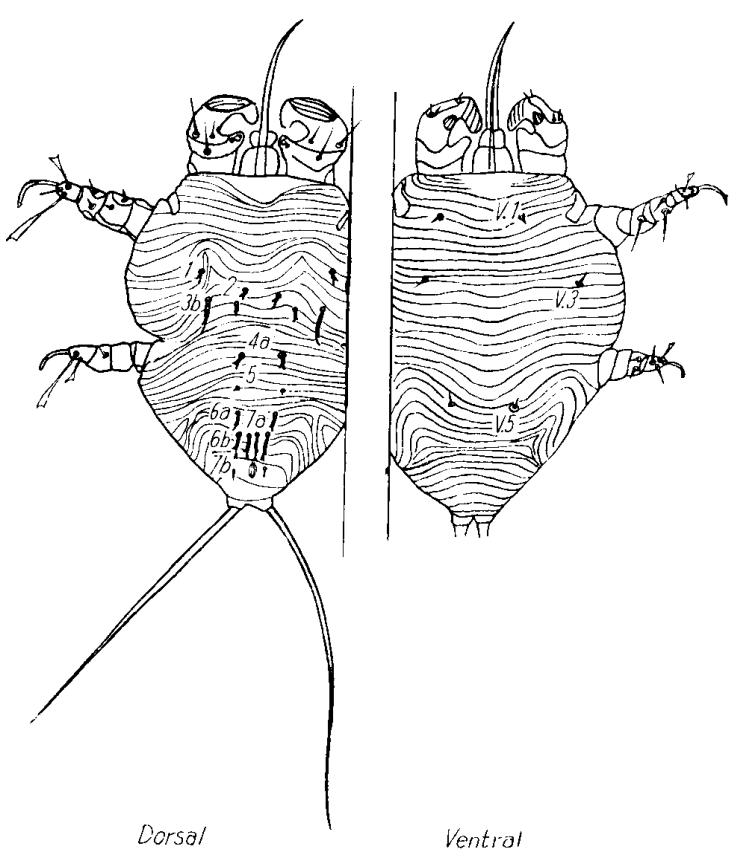

Fig. 13 R. affinis, 2nd larva, dorsal and ventral halves.

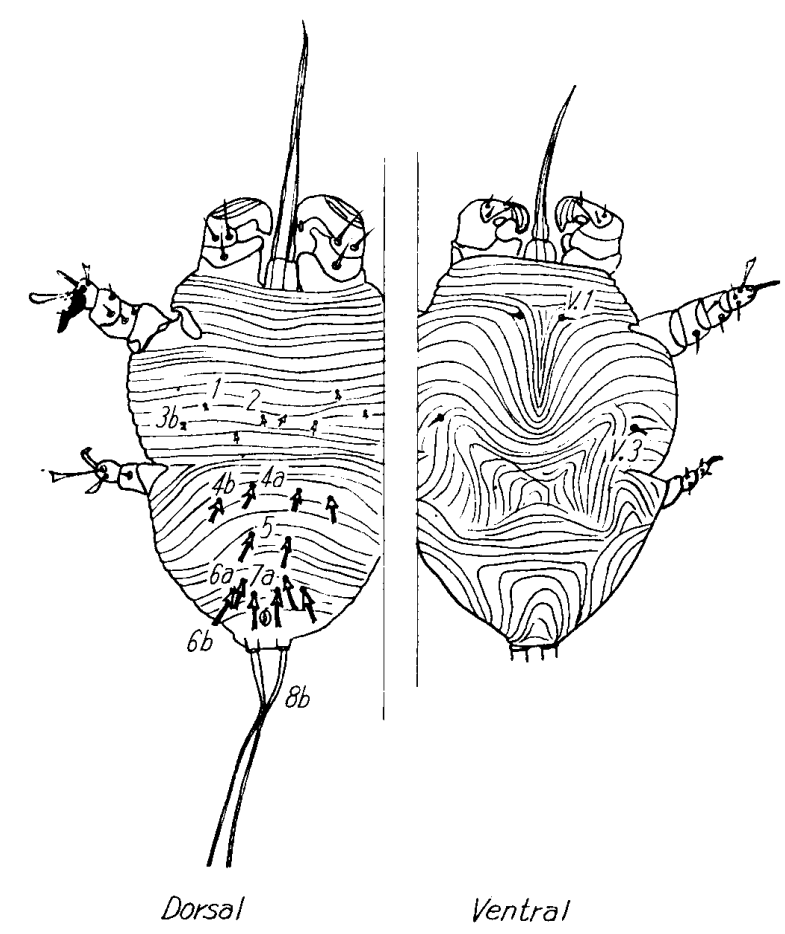

Fig. $14 R$. affinis, lst larva, dorsal and ventral halves.

共通の附属毛を知ることによつて種間発育期間の差異を 記述した[表 6，7][図 15〜24].

基節一附属毛はない.

転節一成虫の 3 本の毛で代表されて, 第 $3 ， 4$ 脚背面 は脚の先端に達する鞭状毛 (Tr.4) があり, 第 2 脚には 短毛があるのみで, 後若虫以下の発育期では第 1 脚は附 属毛を持たない，後若虫の第 2,3 脚には短毛 $(T r .1)$ が 
Table 6 Comparison of the leg-chaetotaxy formula between each stages in $M$. musculi

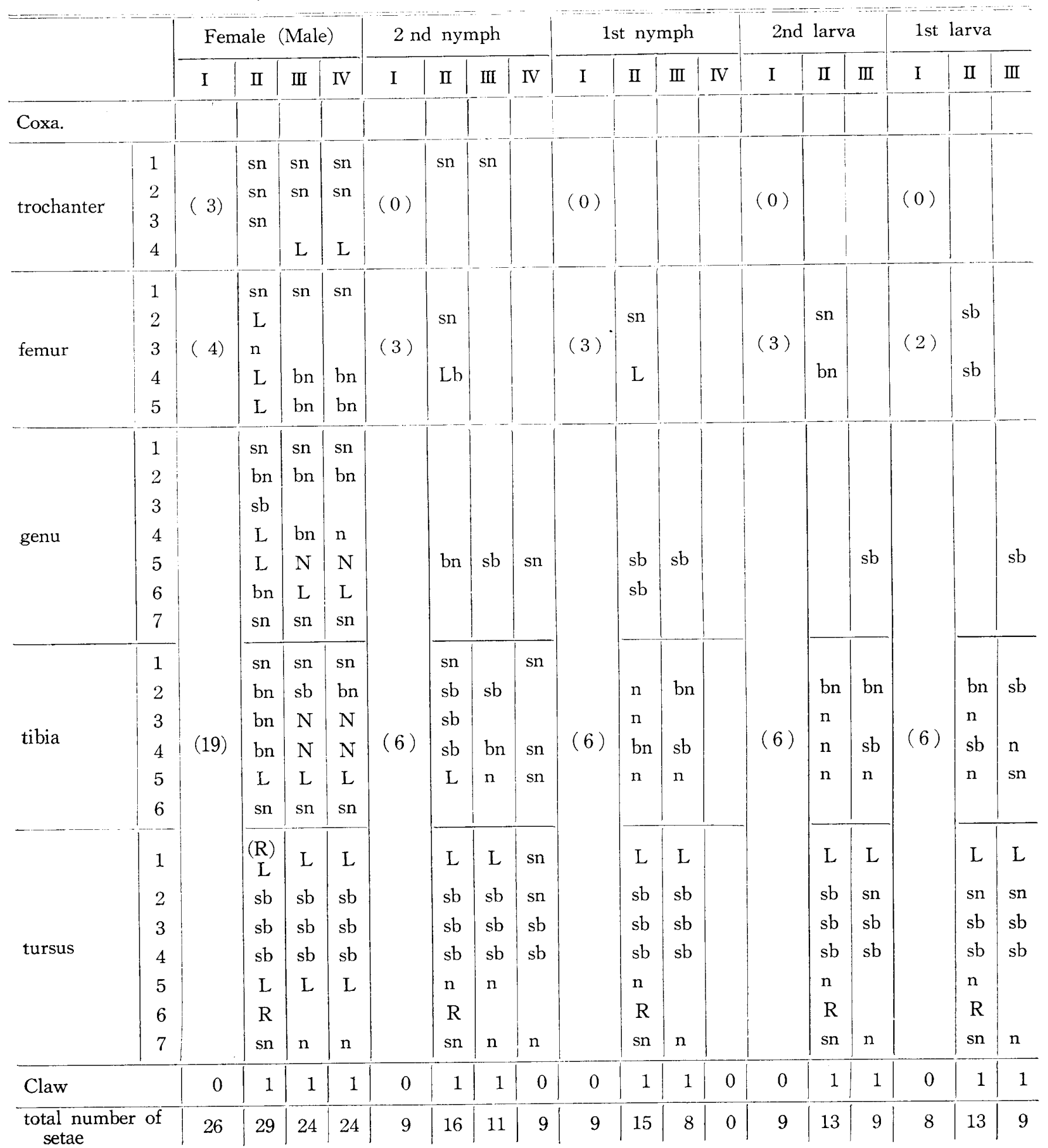

$\mathrm{m}$ : microsetae, $\mathrm{sn}$ : short nude setae $-8, \mathrm{sb}:$ short base broaded setae $-8 \mu, \mathrm{n}:$ nude setae $8.1-30 \mu$, bn : base broaded setae $8.1-3.0 \mu, \mathrm{N}$ : expanded setae, L: Long setae $30.1 \mu-, \mathrm{R}:$ rod setae. 
Table 7 Comparison of the leg-chaetotaxy formula between stages in $R$. affinis

\begin{tabular}{|c|c|c|c|c|c|c|c|c|c|c|c|c|c|c|c|c|c|c|c|}
\hline \multirow{2}{*}{ segments } & & \multicolumn{4}{|c|}{ Female (Male) } & \multicolumn{4}{|c|}{ 2nd nymph } & \multicolumn{4}{|c|}{ 1st nymph } & \multicolumn{3}{|c|}{ 2nd larva } & \multicolumn{3}{|c|}{ 1st larva } \\
\hline & & I & II & III & IV & I & II & III & IV & I & II & III & IV & I & II & III & I & II & III \\
\hline \multicolumn{20}{|l|}{ Coxa. } \\
\hline trochanter & $\begin{array}{l}1 \\
2 \\
3 \\
4\end{array}$ & ( 3$)$ & $\begin{array}{l}\text { sn } \\
\text { sn } \\
\text { n }\end{array}$ & $\begin{array}{l}\text { sn } \\
\text { sn } \\
\text { L }\end{array}$ & $\begin{array}{l}\text { sn } \\
\text { sn } \\
\text { L }\end{array}$ & (0) & sn & sn & sn & (0) & & & & $(0)$ & & & (0) & & \\
\hline femur & $\begin{array}{l}1 \\
2 \\
3 \\
4 \\
5\end{array}$ & ( 4$)$ & $\begin{array}{l}\text { sn } \\
\text { L } \\
\text { n } \\
\text { L } \\
\text { L }\end{array}$ & $\left\{\begin{array}{l}\text { sn } \\
\text { bn } \\
\text { bn }\end{array}\right.$ & $\begin{array}{l}\text { bn } \\
\text { bn }\end{array}$ & (2) & $\mathrm{Lb}$ & $\mathrm{n}$ & sn & (2) & $\mathrm{n}$ & sn & & (2) & $\mathrm{n}$ & & (1) & $\begin{array}{l}\mathrm{sn} \\
\mathrm{n}\end{array}$ & \\
\hline geu & $\begin{array}{l}1 \\
2 \\
3 \\
4 \\
5 \\
6 \\
7\end{array}$ & \multirow{3}{*}{ (22) } & $\begin{array}{l}\text { sn } \\
\text { bn } \\
\text { sn } \\
\text { bn } \\
\mathrm{L} \\
\mathrm{N} \\
\mathrm{bn}\end{array}$ & \begin{tabular}{|} 
sn \\
bn \\
sn \\
bn \\
L \\
sn
\end{tabular} & $\begin{array}{l}\text { sn } \\
\text { sn } \\
\text { bn } \\
\text { L } \\
\text { sn }\end{array}$ & \multirow{3}{*}{ (8) } & $\mathrm{sn}$ & & & \multirow{3}{*}{ (6) } & sn & & & \multirow{3}{*}{ (6) } & $\mathrm{m}$ & & \multirow{3}{*}{ (6) } & $\mathrm{m}$ & \\
\hline tibia & $\begin{array}{l}1 \\
2 \\
3 \\
4 \\
5 \\
6\end{array}$ & & $\begin{array}{l}\text { sn } \\
\text { bn } \\
\text { bn } \\
\text { bn } \\
\mathrm{L} \\
\mathrm{n}\end{array}$ & $\begin{array}{l}\mathrm{sn} \\
\mathrm{bn} \\
\mathrm{N} \\
\mathrm{N} \\
\mathrm{L} \\
\mathrm{n}\end{array}$ & $\begin{array}{l}\mathrm{sn} \\
\text { bn } \\
\mathrm{N} \\
\mathrm{N} \\
\mathrm{L} \\
\mathrm{sn}\end{array}$ & & $\begin{array}{l}\mathrm{sn} \\
\mathrm{sb} \\
\mathrm{n} \\
\mathrm{n}\end{array}$ & $\begin{array}{l}\mathrm{n} \\
\mathrm{n}\end{array}$ & & & $\begin{array}{l}\text { sn } \\
\text { sb } \\
\text { sn } \\
\text { sn }\end{array}$ & $\begin{array}{l}\text { sn } \\
\text { sn }\end{array}$ & & & $\begin{array}{l}\text { sn } \\
\text { sn } \\
\text { sn } \\
\text { sn }\end{array}$ & $\begin{array}{l}\text { sn } \\
\text { sn }\end{array}$ & & $\begin{array}{l}\mathrm{sn} \\
\mathrm{sn} \\
\mathrm{sn} \\
\mathrm{sn}\end{array}$ & $\begin{array}{l}\text { sn } \\
\text { sn } \\
\text { sn }\end{array}$ \\
\hline tarsus & $\begin{array}{l}1 \\
2 \\
3 \\
4 \\
5 \\
6 \\
7\end{array}$ & & $\mid \begin{array}{c}\mathrm{L} \\
\mathrm{sn} \\
\mathrm{sb} \\
\mathrm{sb} \\
\mathrm{bn} \\
\mathrm{R} \\
\mathrm{sn}\end{array}$ & $\begin{array}{c}\mathrm{L} \\
\mathrm{sb} \\
\mathrm{sb} \\
\mathrm{sb} \\
\mathrm{bn} \\
\mathrm{n}\end{array}$ & $\begin{array}{c}\mathrm{L} \\
\mathrm{sb} \\
\mathrm{sb} \\
\mathrm{sb} \\
\mathrm{bn} \\
\mathrm{n}\end{array}$ & & $\begin{array}{c}\text { eL } \\
\text { en } \\
\text { sn } \\
\text { sn } \\
\text { bn } \\
R \\
\text { en }\end{array}$ & $\begin{array}{l}\text { eL } \\
\text { en } \\
\text { sn } \\
\text { sn } \\
\text { bn } \\
\text { sn }\end{array}$ & & & $\begin{array}{l}\text { eL } \\
\text { en } \\
\text { sn } \\
\text { sn } \\
\text { en } \\
R \\
\text { en }\end{array}$ & $\begin{array}{l}\text { eL } \\
\text { en } \\
\text { sn } \\
\text { sn } \\
\text { en }\end{array}$ & & & $\begin{array}{l}\text { eL } \\
\text { en } \\
\text { sn } \\
\text { sn } \\
\text { en } \\
R \\
\text { en }\end{array}$ & $\begin{array}{l}\text { eL } \\
\text { en } \\
\text { sn } \\
\text { sn } \\
\text { en }\end{array}$ & & $\begin{array}{c}\text { eL } \\
\text { en } \\
\text { sn } \\
\text { sn } \\
\text { en } \\
\mathrm{R} \\
\text { en }\end{array}$ & $\begin{array}{l}\text { en } \\
\mathrm{R} \\
\mathrm{sn} \\
\text { sn } \\
\\
\text { en }\end{array}$ \\
\hline \multicolumn{2}{|l|}{ Claw } & 0 & 2 & 1 & 1 & 0 & 1 & 1 & 0 & 0 & 1 & 1 & 0 & 0 & 1 & 1 & 0 & 1 & 1 \\
\hline \multicolumn{2}{|c|}{$\begin{array}{l}\text { total number } \\
\text { of setae }\end{array}$} & 29 & 28 & 24 & 23 & 10 & 16 & 11 & 2 & 8 & 15 & 9 & 0 & 8 & 14 & 8 & 7 & 14 & 9 \\
\hline
\end{tabular}

$\mathrm{m}$ : microsetae, sn: short nude setae $-8 \mu, \mathrm{sb}$ : short base broaded setae $-8 \mu, \mathrm{n}$ : nude setae $8.1-30 \mu$, bn : base broaded setae $8.1-30 \mu, \mathrm{N}$ : expanded setae, L : long setae $30.1 \mu-,, \mathrm{R}$ : rod setae, e : tip expanded setae. 

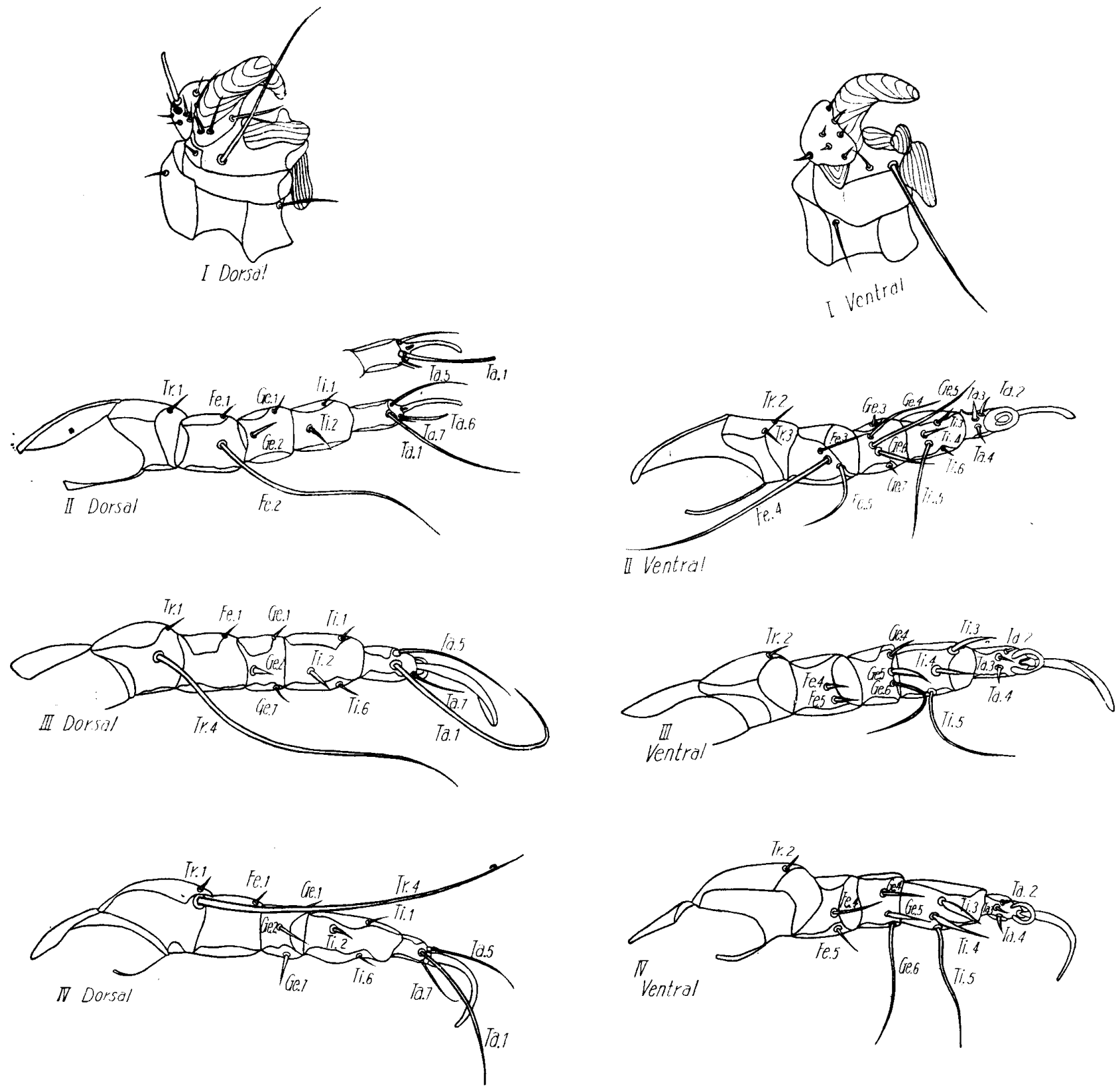

Fig. 15 M. musculi, Adult, legs I-IV

I : leg I, II : leg II, III : leg III, IV : leg IV, Cx : coxa, Tr : trochanter, $\mathrm{Fe}$ : femur, Ge: genu, Ti : tibia, Ta: tarsus. 
(18) 衛 生 動 物 1961 年 Vol. 12 No. 1

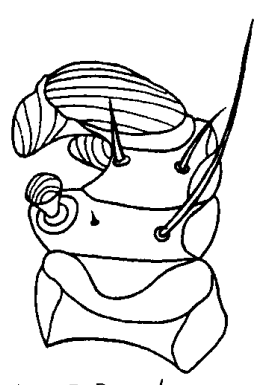

I Dorsal
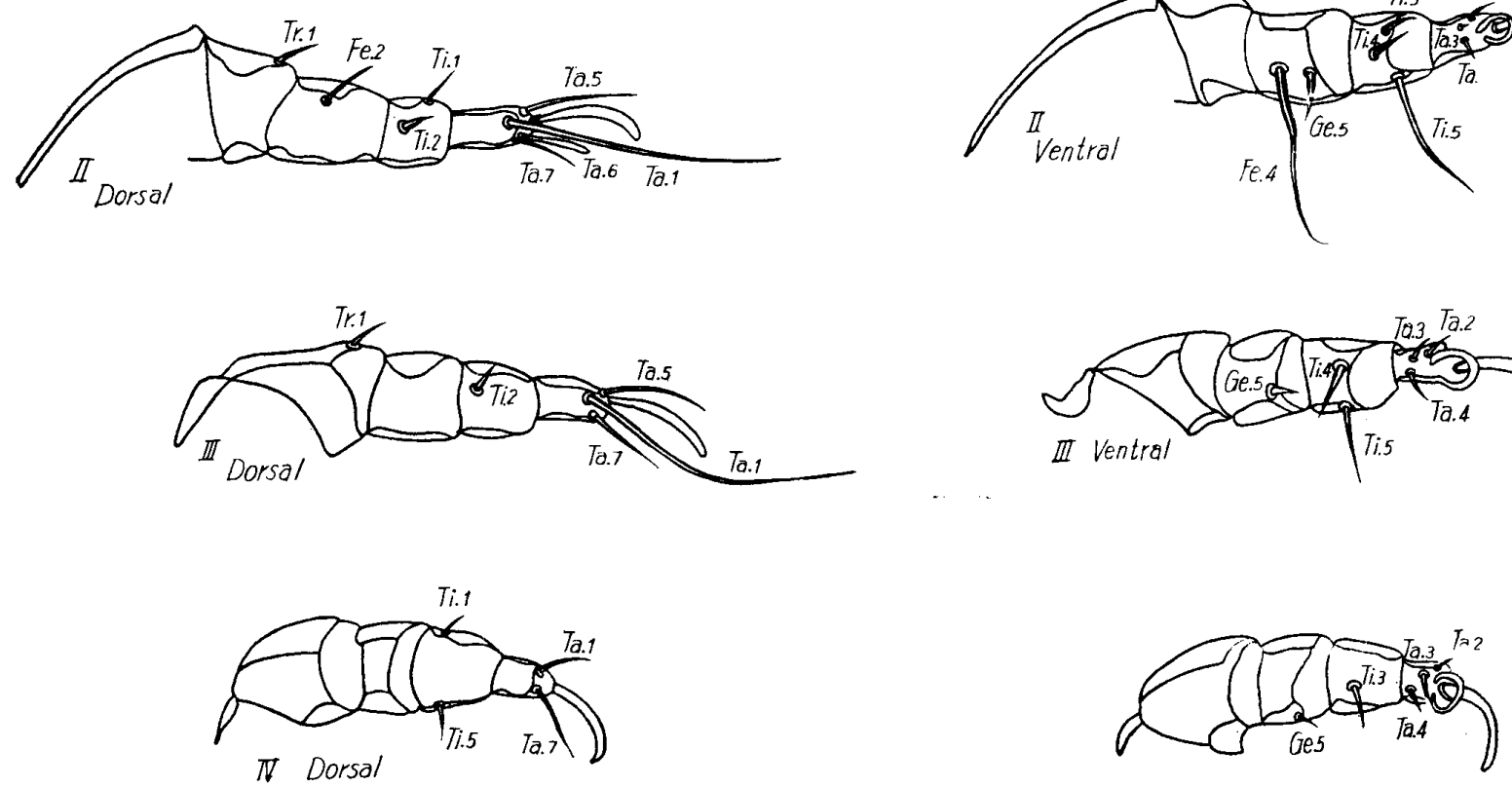

Fig. $16 M$. musculi, 2nd nymph, legs I-IV
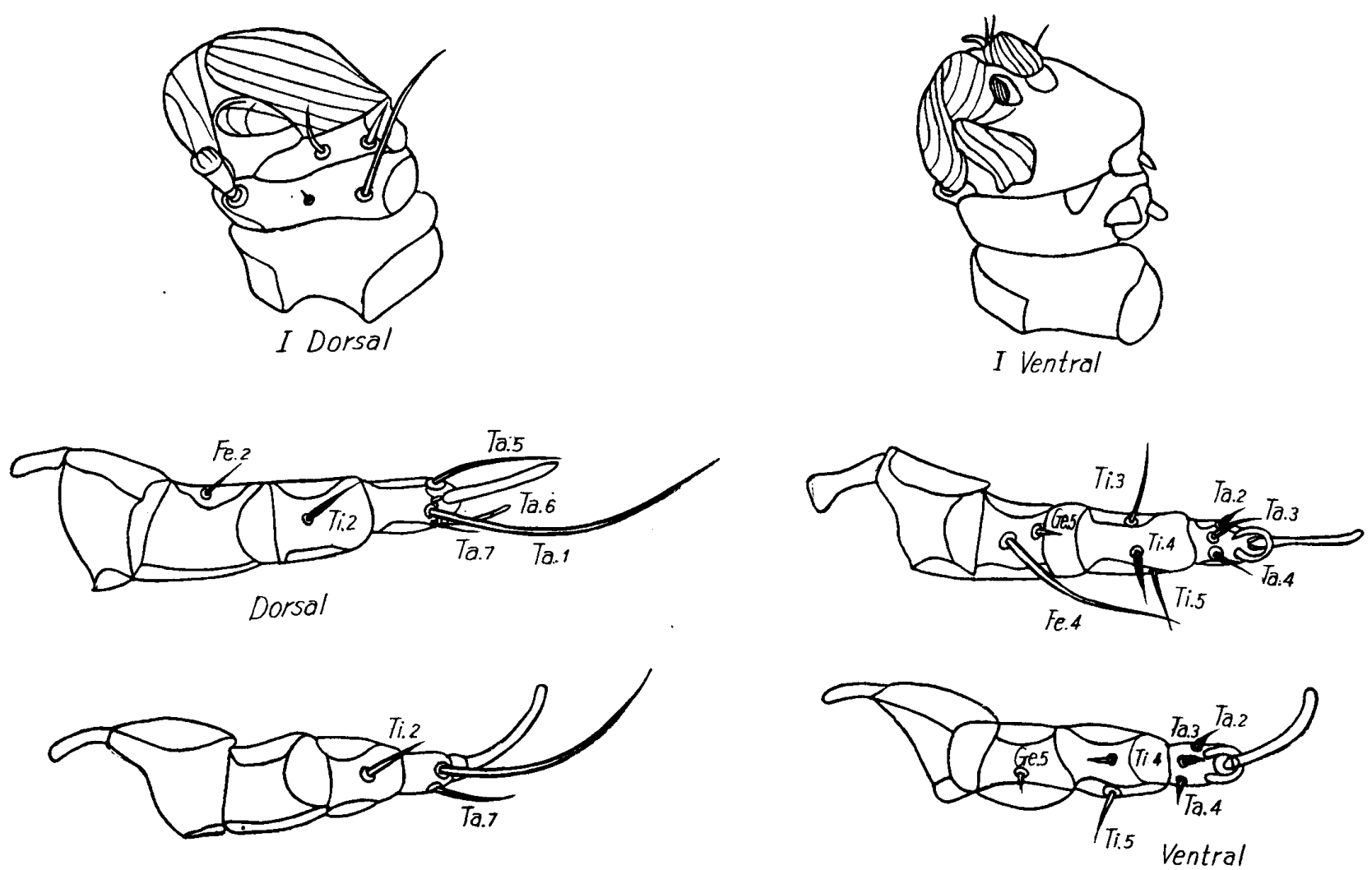

Fig. 17 M. musculi, lst nymph, legs I-III 

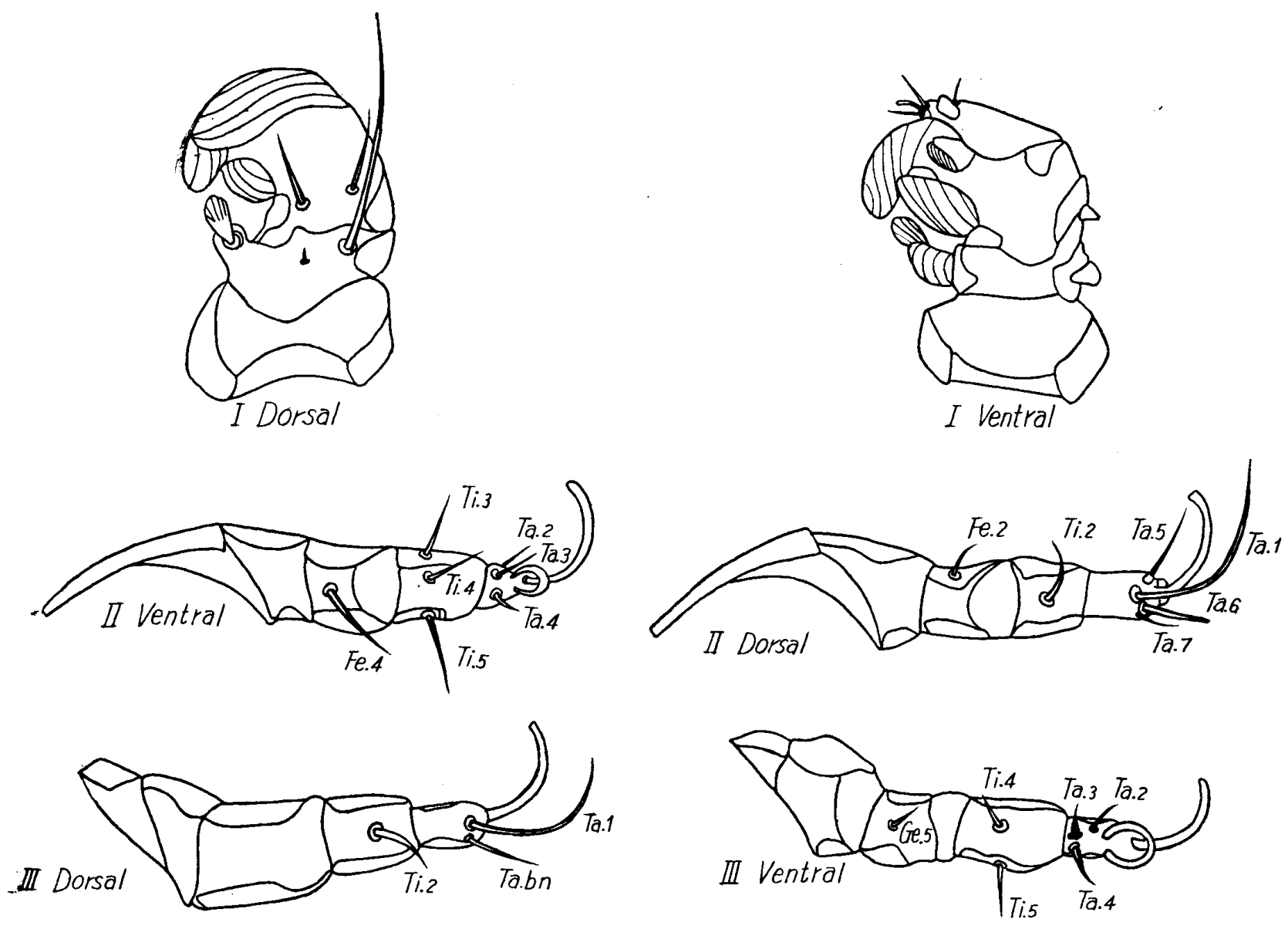

Fig. $18 M$. musculi, 2nd larva, legs I-III
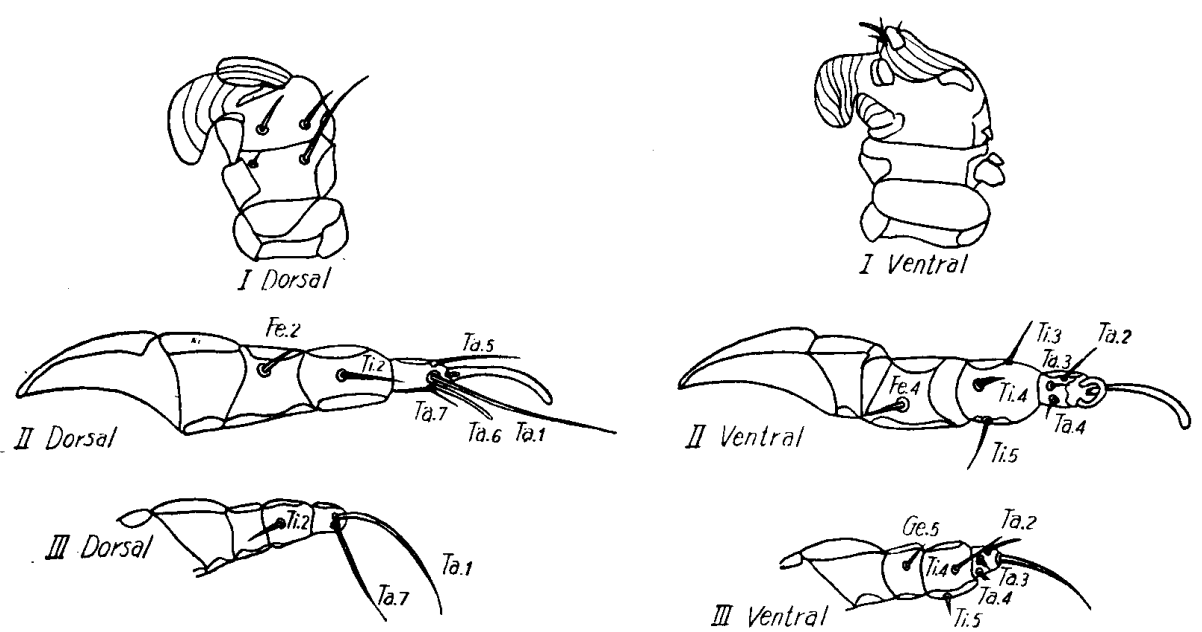

Fig. 19 M. musculi, lst larva, legs I-III 


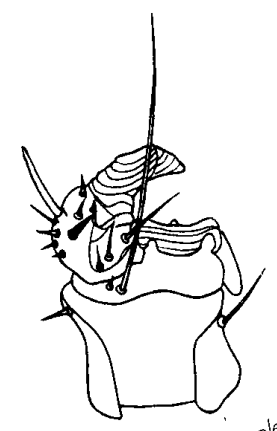

I Dorsal temate
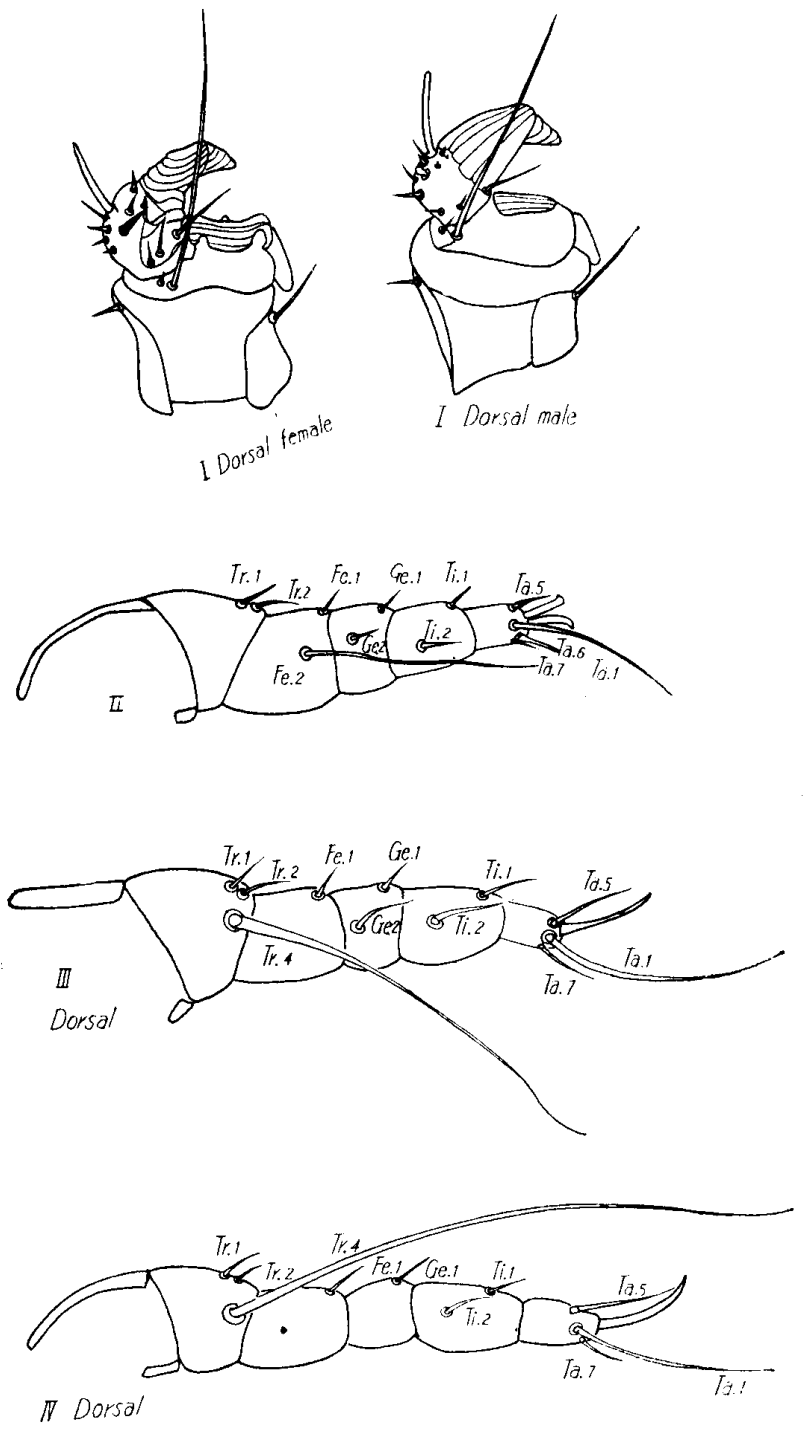

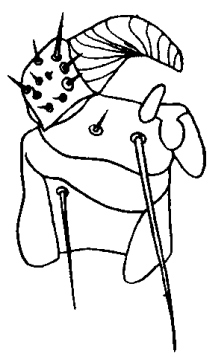

I Ventral
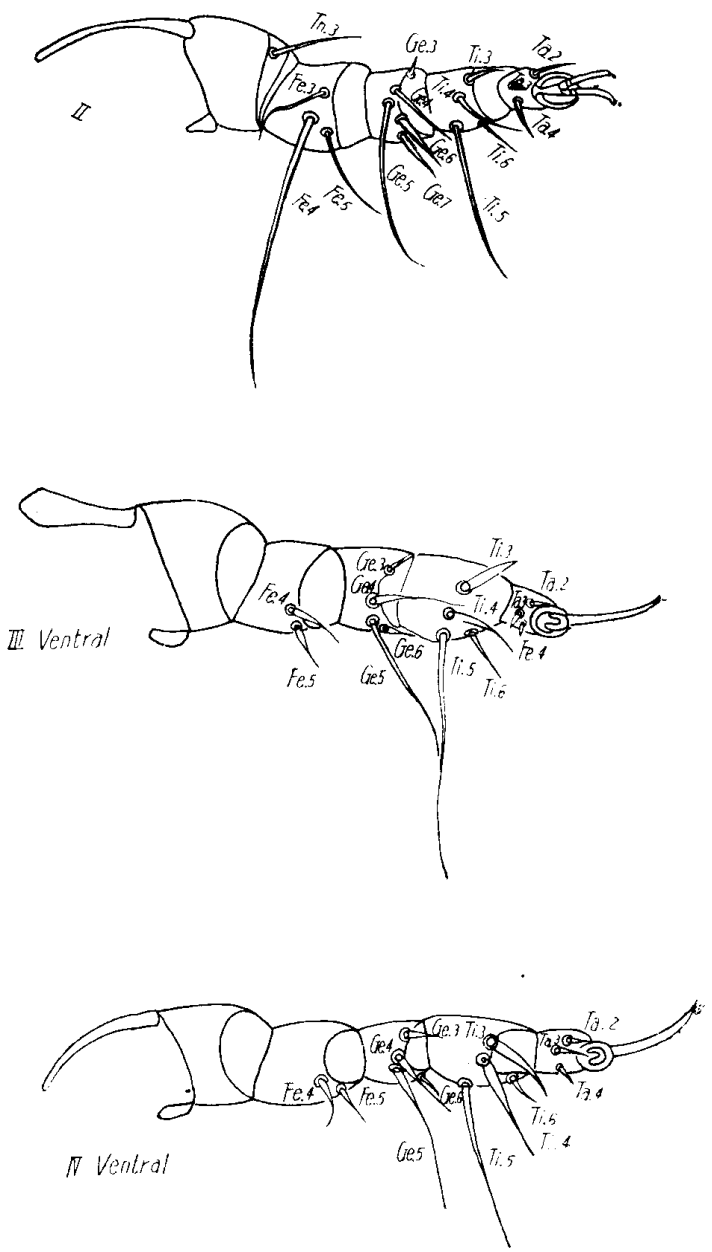

Fig. 20 R. affinis, Adult, legs I-IV 

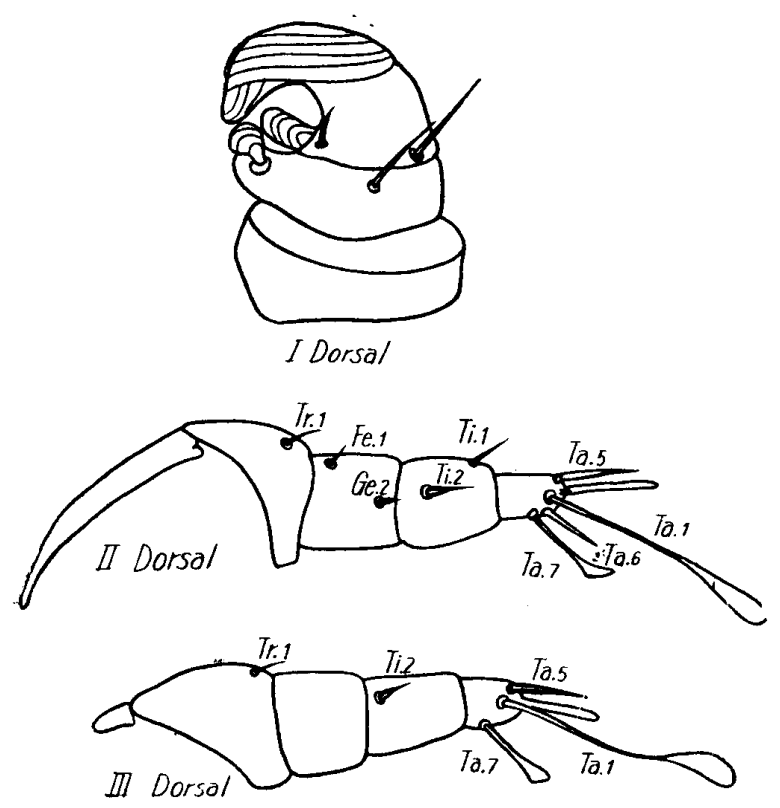
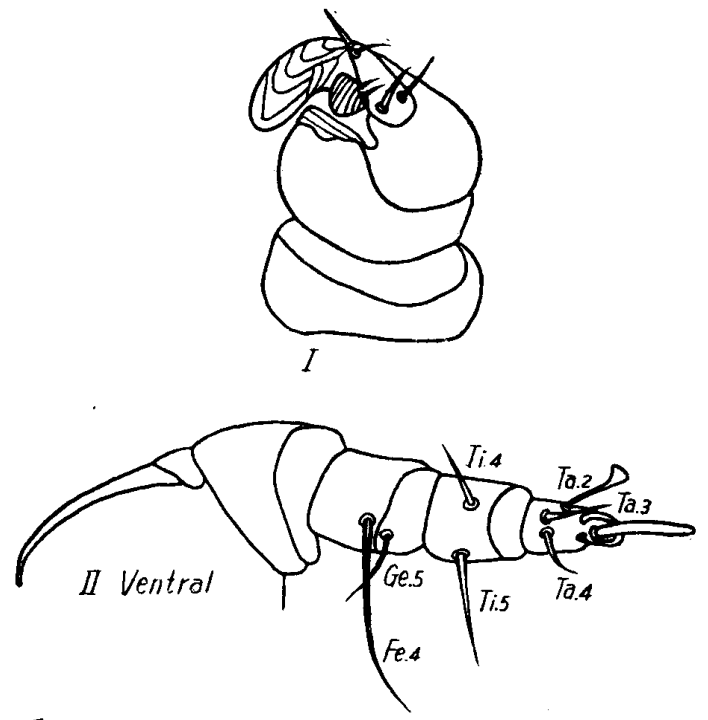

$\checkmark$
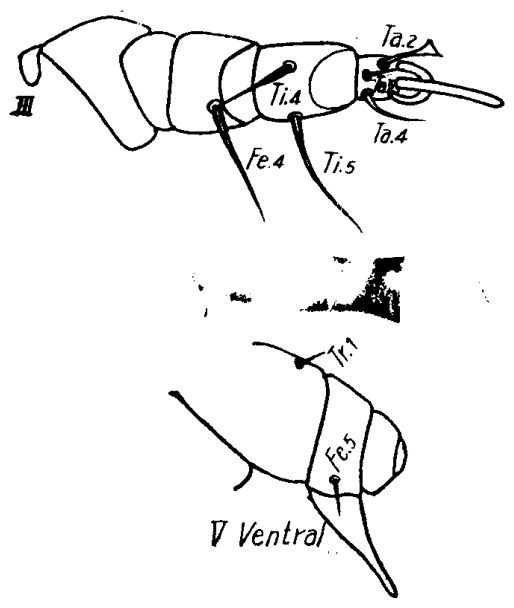

Fig. $21 R$. affinis, 2nd nymph, legs I-IV
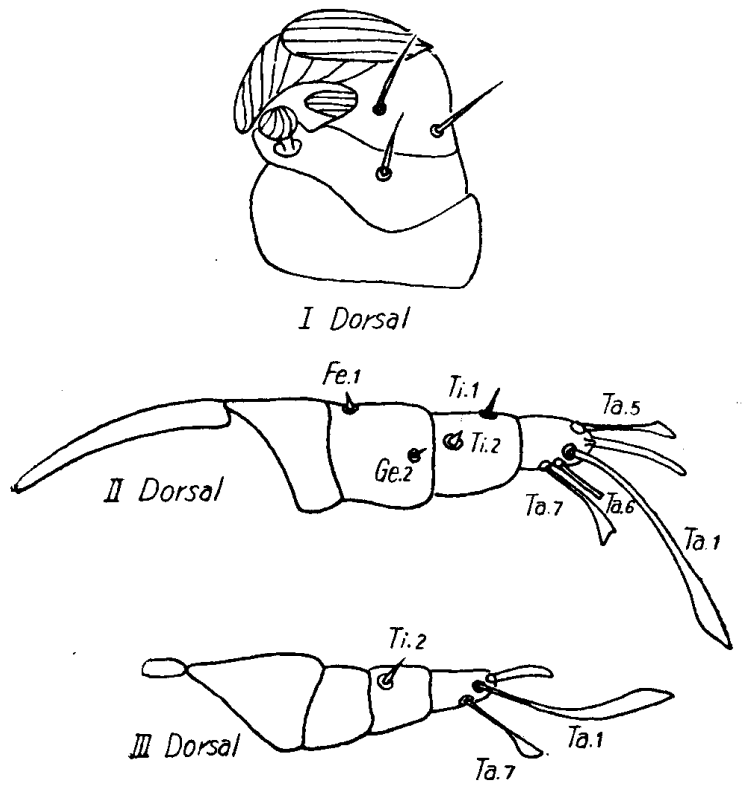
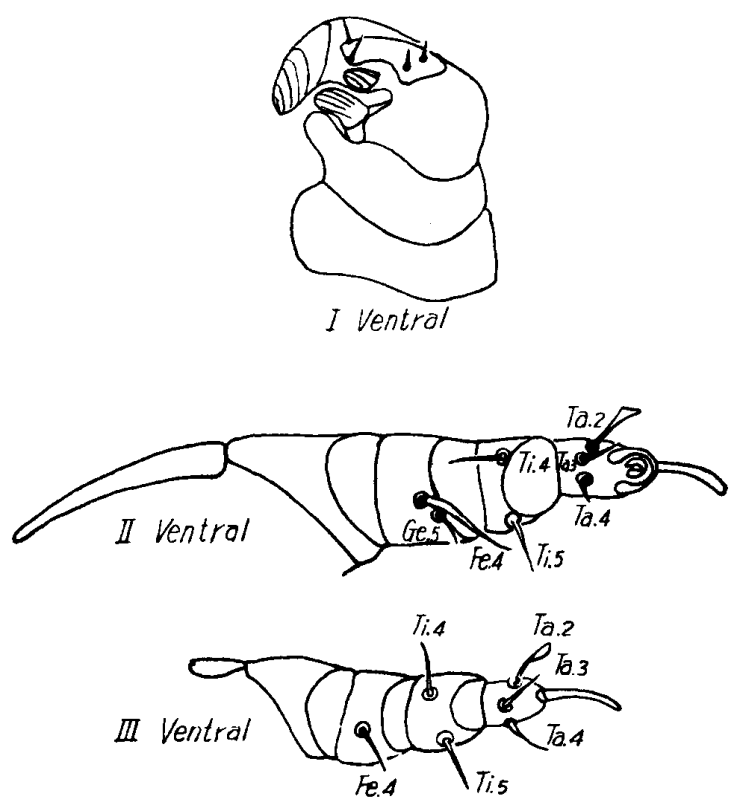

Fig. $22 R$. affinis, lst nymph, legs I-III 

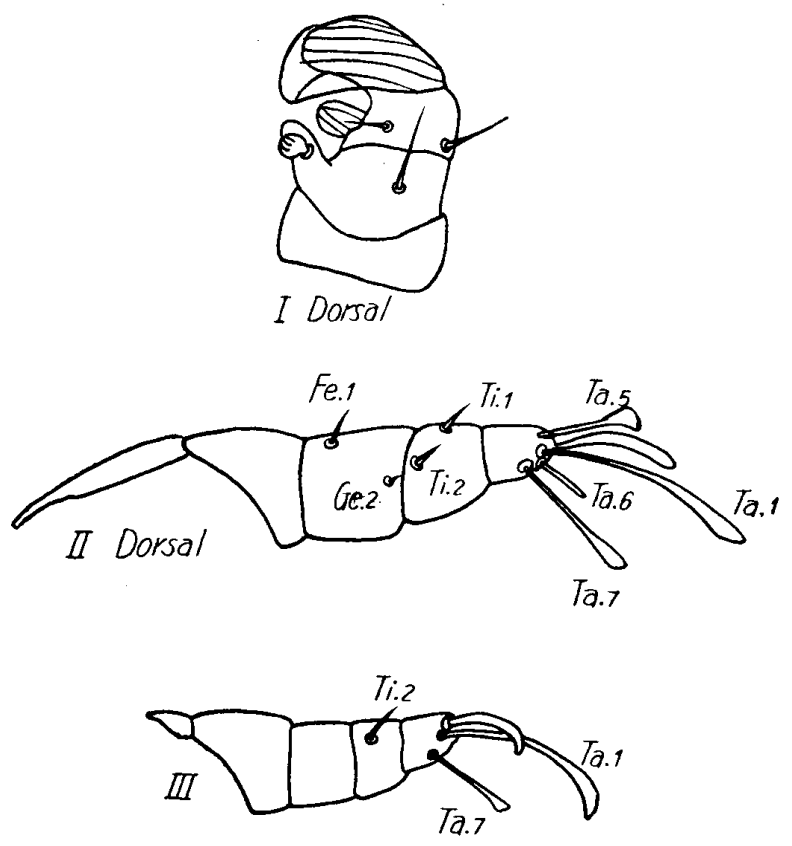
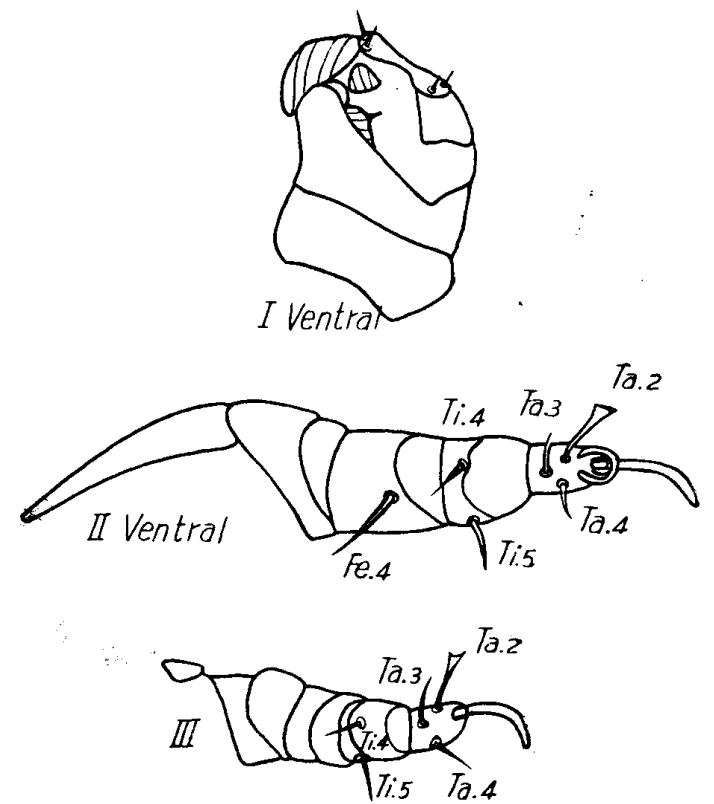

Fig. $23 \quad R$. affinis, 2nd larva, legs I-III
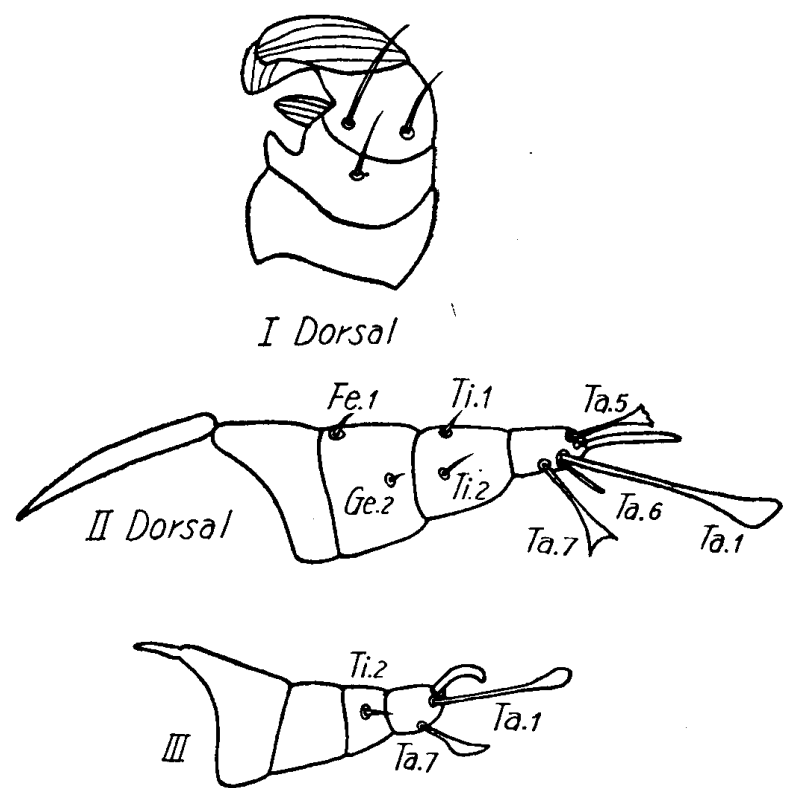

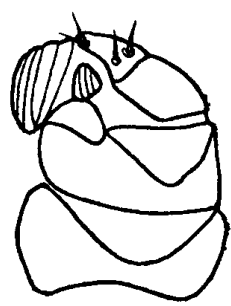

I Ventral
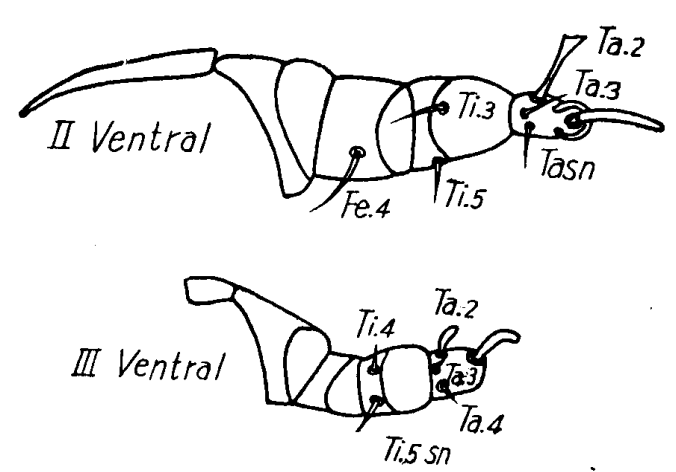

Fig. $24 R$. affinis, lst larva, legs I-III 


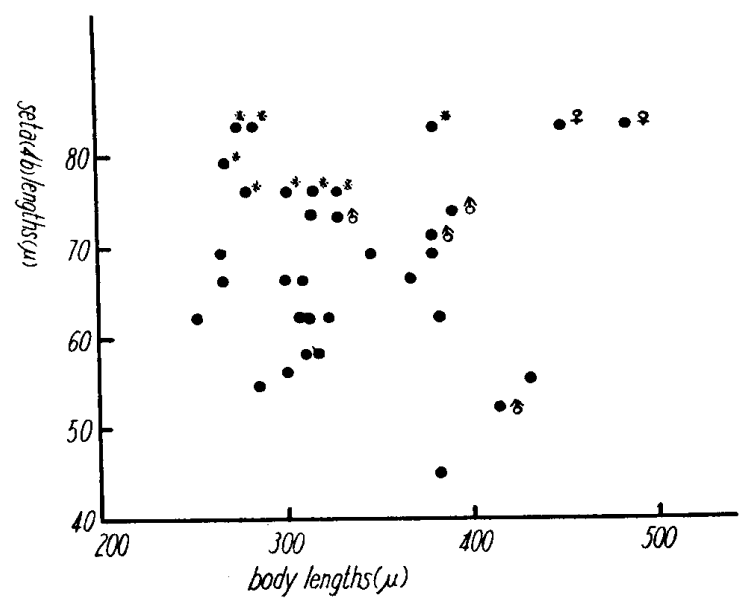

Fig. 25 Relation between body and dorsal setae ( $4 \mathrm{~b}$ ) lengths.

ある．前若虫以下では附属毛は存在しない，

腿節一成虫第 2 脚は 5 本の附属毛を持ち，その内第 1 脚は背・腹両面に長毛 $(\mathrm{Tr} .2 ， 4)$ があり，第 $2 ， 3$ 脚の Tr. 4 にほぼ匹敵する.この附属毛は第 1 脚においても 存在する.第 $3 ， 4$ 脚では Fe. 2，3がない. 若虫と幼虫 の第 2 節は附属毛の配置から成虫の腿節と膝節が未分節 の状態にあると考えられる.すなわち，腹面の前後にな らんだ毛 (Fe. 4, Ge. 5)があり,さらにR. affinisに は背面に成虫の Fe. 1 と G. 2 に相当する附属毛が存 在する. M. musculi の若虫・幼虫期と R. affinis の 幼虫期は第 3 脚に附属毛がない.

膝節一成虫は第 2 脚の 7 本の毛によつて代表される. M. musculi では第 3，4 脚の Ge. 3 が，R. affinis で は第 $3 ， 4$ 脚の Ge. 7 と第 4 脚の $\mathrm{Ge} .2$ がない. $M$. musculi の第 3,4 脚の Ge. 5 と R. affinis の第 2 脚の Ge. 6 池他の毛より幅広く，両種の区別点となる. 若 虫・幼虫期を通じて，M. musculi では第 3 脚に Ge. 5 があり，R. affinis では第 2 脚に Ge. 2 がある. 第 2 脚 の Ge. 5 は若虫期を構成する特徵である.

脛節一成虫は 6 本の毛で構成され. 各脚による差はあ まりない.しかし第 $3 ， 4$ 脚の Ti. 3，4 は M. musculi の Ge. 5, R. affinis の Ge. 6 と同様の幅広い毛であ る. M. musculi の若虫・幼虫は, 第 2 脚に 5 本, 第 3 脚に 3 本の附属毛を持つが，R. affinis は第 2 脚の $T i$. 3 が欠けて 4 本である. 後若虫の第 4 脚は M. musculi のみ 4 本の附属毛を持つ。

囉節一先端に肉盤と，爪を持つ. 成虫は第 2 脚の 7 本 が最も多く，第 $3 ， 4$ 脚では Ta. 6 がない. Ta. 6 は全 発育期を通じて第 2 脚の爪の側方にあり, 棍棒状（rod seta) の特殊な毛である. 背面末端毛(Ta. 1) は長い鞭状 毛であるが，M. musculi の雄では長い棍棒状毛であ る. 前若虫・幼虫では, 第 3 脚の Ta. 5 がない. $R$. affinis では若虫・幼虫期における Ta. 1，2，5，6 は先 端がふくらんでいる. また成虫 (雄) は若虫・幼虫の第 1 脚第 2 節にある瘤状に先のふくらんだ毛の小形のものを 第 1 脚，第 3 節に有する.

以上脚の chaetotaxy の結果, M. musculi と R. affinis は，非常に類似した性質と配置が示された.この 2 種 の特徴を比較すれば次のとおりで, 成虫では R. affinis の第 3 脚の Ge. 7 と第 4 脚の Ge. 2, Ge. 7 が久けて おり, M. musculi では第 3,4 脚の Ge. 3 が久けてい る. 若虫・幼虫では, M. musculi の第 1 脚の第 2 節の 背面に長・短 2 本の毛があるが $R$. affiuis には長毛の みであつて短毛はない.さらに $R$. affinis には，第 2 脚に Ge. 2 があるが，M. musculi にはない.また， 第 3 脚の第 2 節腹面にある短毛は $M$. musculi では成 虫の Ge. 5, R. affinis では Fe. 4 と考えられる. 前幼 虫では，M. musculi の第 3 脚の膝節腹面毛 $(\mathrm{Ge} .4)$ は R. affinis で欠ける.

各発育期を追つて行くことによつて，胴背毛 $4 \mathrm{a} ， 5$, $6 \mathrm{a}$ は他の胴背毛と同じく側刺を持つた毛を起源として おり, また, 幼虫時代にはまゔ後方の毛より発達し, 若 虫特に成虫では,むしろ, 前方の毛がより発達する傾向 にあることが知られた。

胴背部の Chaetotaxy の結果, $R$. affinis の後若虫に 胴背毛 1，2，3a，4a，6a がよく発達している[図 10] む のと，極めて未発達で前若虫とこれらの毛がほとんど変 らない[図 11]2 型が知られた. 前者には睢が，後者には 雄が，形成されることを確め得た.そこで，このような 性差の存在を M. musculi について検討を加えた結果, 胴背毛に一見しての差異は見出し得なかつたが，体長と 胴背毛 46 の測定の結果図 25 に示すごとく，雌型と雄型 がこの時期から $4 \mathrm{~b}$ の長さに表われる傾向が知られた.

(図中の ・ ・古の記号後若虫体内に形成された成虫に よつて, 性を確め得たもの).

脚の chaetotaxy の結果, 附属毛は第 2 脚に数多く, かつ, 囉節は複雑であり, 若い発育期においてもよく発達 していることが知られた， R. affinis の属の特徵である 成虫の 1 対の爪は, 若虫・幼虫時代 1 本の爪よりなり, 両属を鑑別する手がかりとならないよつてこの時期に おける $M$. musculi の胴背毛 $4 \mathrm{~b}$ と $R$. affinis の $3 \mathrm{~b}$ は 早期からよく発達してそれぞれの幼・若虫期を代表する ので, 両種の鑑別に重要である・

両種の附属毛の種類は多くなく, 次のごとくである： 胴背毛は微·短・長 3 種の裸毛，縦縞を有し側刺を 1 ない し 2 本持つ毛とそれらの基部の肥大したもの等であり， 
脚毛は微・短・長 3 種の裸毛，それらの基部の肥大した 毛, 棍棒状毛, 先端が瘤状に肥大した毛, 先端が膜状に 肥大した毛によつて構成される.

\section{ま と}

1960 年春以来皮膚にかかつているマウスから Myobiid mites を採集し，それについて分類学的，形態学 的考察を行つた。この度採集された Myobiid mite は Myobia musculi と Radfordia ffianis で, 両種とも発 育期について記載することができた. そしてこの両種と 各発育期間の胴部と脚について chaetotaxy を比較する ことができた。

\section{参考文献}

1) Baker, E. W. (1949): A review of the mites of the family Cheyletidae in the United States National Museum. Proc. U. S. Nat. Mus., 99 : 297. -2) Baker, E. W. \& Wharton, G. W. (1952) : An Introduction to accarology. Macmillan. co., New York. -3) Baker, Evans, Gould, Mull, Keegan (1956) : A Manual of Parasitic Mites. A Technical Publication of the National Pest Control Association, Inc. New York. -4) Barker, E. W., Camin, J. H., Cunliffe, F., Wooley, T. A. \& Yunker, C. E. (1958): Guide to the Families of Mites. Institute of Acarology Department of Zoology Univ. of Maryland, pp. 242.-5) Charles, D. \& Radford, C. D. (1938): Notes on some new species of parasitic mites. Parasit., $30(4): 427-440$. -6) Charles, D. \& Radford, C. D. (1939): Notes on some new species of parasitic mites. Parasit., $31(2)$ : 243254. -7) Charles, D. \& Radford, C. D. (1940) : Notes on some new species of parasitic mites. Parasit., 32(1) : 91-104. -8) Ewing, H. E. (1938) : North American mites of the subfamily Myobiinae, new subfamily (Arachnida). Proc. Ent. Soc. Wash., 40 : 180-197. -9) Grant, C. D. (1942) : Observation on Myobia musculi (Schrank) (Arachnida : Acarina : Cheletidae). Microent., 7(3) : 64-76. 10) Jameson, E. W. (1948) : Myobiid mites (Acarina: Myobiinae) from shrews (mammalia : Soricidae) of Eastern North America. Jour. Parasit., 34 (4) : 336-346. -11) Jameson, E. W. (1949) : Myobiid mites (Acarina: Myobiidae) from Condylura cristata (Linnaeus) and Neurotrichichus gibbsii (Baird) (Mammalia : Talpidae). Jour. Parasitol., 35 : 423-430. -12) Jameson, E. W., Jr. \& Chow, C. Y. (1952) : Pteracarus, a new genus of myobiid mites (Acarina : Myobiidae) from bats (Mammalia : Chiroptera). Jour. Parasit., 38(3) : 1-4. -13) Jameson, E. W.(1955): A summary of the genera of Myobiidae (Acarina). Jour. Parasit., 41: 407-416. -14) Madden, A. H., Tozloshki, A. H. (1954) : Control of myobia musculinus(Shank) and Myocoptes musculinus (Koch) on laboratory mice. J. Econ. Ent., 47 : 442-444. -15) Poppe, S. A. (1896) : Beitrag zur Kenntnis der Gattung Myobia v. Heyden. Zool. Anz., 19 : 337-349. -16) Radford, C. D. (1935) : Notes on mites of the genus Myobia. Part 2. North West. Nat., Sep., 248-258. -17) Radford, C. D. (1936): Notes on the mites of the genus Myobia. Part 3. North West. Nat., March, 34-39.-18) Radford, C. D. (1936) : Notes on mites of the genus Myobia. Part 4. North West. Nat., June, 144-151.19) Radford, C. D. (1938): Nortes on some new species of parasitic mites. Part. 1. Parasit., 30 : 427440. - 20) Radford, C. D. (1939) : Notes on some new species of parasitic mites. Part 2. Parasit., 31 : 243-254. -21) Radsord, C. D. (1940) : Notes on some new species of parasitic mites. Part 3. Parasit., 32 : 91-104. -22) Radford, C. D. (1941) : Notes on some newspecies of parasitic mites. Part 4. Parasit., 33 : 306-315. - 23) Radford, C. D. \& Charles, D. (1949): A revision of the fur mite Myobiidae (Acarina) Bull. Mus. Nationa. Hist. Nat. Paris., 21 (6) : 692-696.-24) Radford, C. D. \& Charles, D. (1950): A revision of the fur mites Myobiidae (Acarina) (suite). Bull. Mus. Nationa. Hist. Nat. Paris, 22 (3) : 360-362. -25) Radfoad, C. D. \& Charles, D. (1950) : A revision of the fur mites Myobiidae (Acarina) (suite). Bull. Mus. Nationa. Hist. Nat. Paris., 22(4) : 462-469. -26) Robart, J. Flynn (1946) : Ectoparasites of mice. Argonne National Laboratory. -27) Wharton, G. W. (1954) : Life cycle and feeding habits of Myobia musculi (Abstract). Jour. Parasit., $40(5 \mathrm{sec} .2)$ : 29. -28) Zumpt, F. (1955): The mange-causing mites of the genus psorergates (Acarina; Myobiidae) with description of a new species from a south african monkey. Parasit., 45(1 $\cdot 2)$ : 269-274.

\section{Summary}

A taxonomic and morphological observation was done on the specimens of myobiid mites collected from laboratory mice suffering from skin lesions. These mites composed of Myobia musculi and Radfordia affinis were described of their four stages in life history, and the comparison in chaetotaxy of dorsum and legs was made between each species and stages. 